\title{
مدى ممارسة مديري المدارس لتفويض الصلاحيات لوكلائهم من وجهة نظر الوكلاء في المدارس المتوسطة والثانوبة بمحافظة الطائف
}

\author{
د. بانقا طه الزبير حسين \\ أستاذ مساعد- قسم أصول التربية والإدارة التزبوية- جامعة الخرطوم- السودان \\ banagataha@gmail.com \\ حسن بن نوار بن ملحم المقاطي \\ مشرف تربوي- مكتب التعليم شمال الطائف- المملكة العربية السعودية
}

\section{الملخص:}

هدفت الدراسة التعرف على مدى ممارسة مديري المدارس لتفويض الصلاحيات لوكلائهم من وجهة نظر الوكلاء في

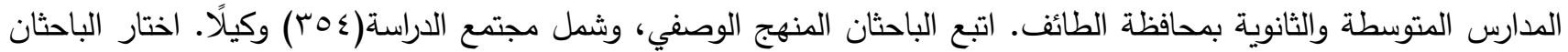

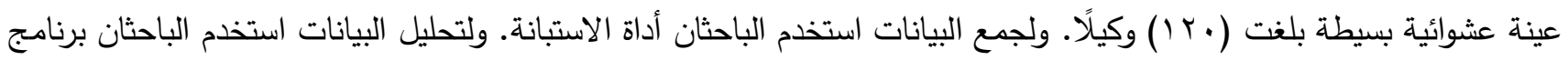
الحزم الإحصائية SPSS. وتوصل الباحثان إلى العديد من النتائج أهمها: ممارسة مديري المدارس لتفويض الصنات التاحيات لوكلائهم جاءت بدرجة ممارسة عالية. وممارسة مديري الددارس لتفويض الصلاحيات لوكلائهج في التخطيط، التتظيم، الإشراف الفني، والتقويم جاءت بدرجة ممارسة عالية. وإن معوقات تفويض الصلاحيات لدى مديري المدارس لتفويض الصلاحيات لوكلائهم جاءت بدرجة عوق كبيرة. وفي ضوء تلك النتائج أوصى الباحثان بضرورة التأكيد على تطبيق تفويض الصدلاحيات لوكلاء المدارس. و وكذلك

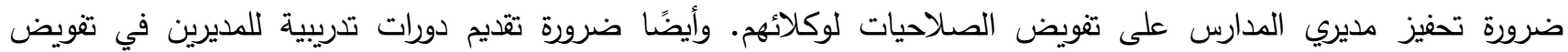
الصلاحيات. وعمل ورش مناسبة عن تفويض الصلاحيات.

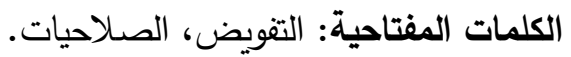

المقدمة:

يشهر العصر الذي نعيش فيه تطورًا في جميع المجالات وخاصة الجوانب الإدارية للمؤسسات التربوية في الوقت الذي تزامن معه التطور في المسؤوليات والواجبات والمهام لمدير المدرسة، وقامت وزارة التربية والتعلم باستحداث برنامج منظم لأعمال مدير

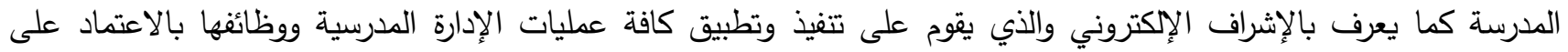
البرنامج الإداري، والذي عن طريقه يتم إعطاء الصلاحيات من قبل مدير البرنامج وهو مدير المدرسة إلى الوكيل والمرشد الطلابي لإلي لئي ورائد النشاط ويقوم المدير بالمتابعة والتوجيه لسير العمل. كما تسعى وزارة التربية والتعليم إلى تذليل العقبات ومواجهة المشكلات الإدارية لنظام المركزية عن طريق تقويض صلاحيات الرئيس إلى المرؤوسين. ويعد تفويض السلطة أمرًا أساسيًا في الهيكل التنظيمي للمنظمات ومنها المنظمات الإدارية. فكلما زاد تفويض السلطة زادت اللامركزية والعكس صحيح. يعتبر التقويض عنصرًا أساسيًا وضروريًا لوظيفة المدير • وإذا استخدم بفعالية فإنه يترتب عليه منافع ومزايا حقيقية لكل طرف رفات في عملية التفويض. إن التفويض يعطي نتائج أفضل، سواءً تم التفويض في المهام اليومية الصغيرة أو مهام القيادة الأساسية 
(برس، ا . .ب: 0). ولوكيل الددرسة دور مماثل للمدير من حيث المسؤوليات والمهام التي يجب أن يقوم بها، ومسؤوليات وكيل

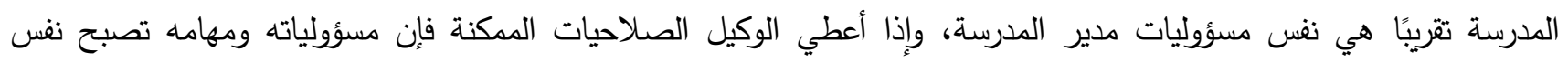
مسؤوليات مدير المدرسة، ولو تغيب مدير المدرسة فإن الوكيل يقوم بجميع الأعمال والمهام التي يقوم بها مدير المدرسة. وجاء في في فئي القواعد التظيمية لمدارس التعليم العام الصادرة من قبل وزارة المعارف، يقوم وكيل المدرسة بمساعدة المدير في أداء الأعمال التربوية

والإدارية وينوب عنه في حالة غيابه (وزارة المعارف، 999 (1) 09 1). كما يجب علينا أن نتذكر دائًًا أن الصلاحيات تفوض بينما المسؤولية لا تفوض. وقد توند تم تطوير صلاحيات مدير المدرسة

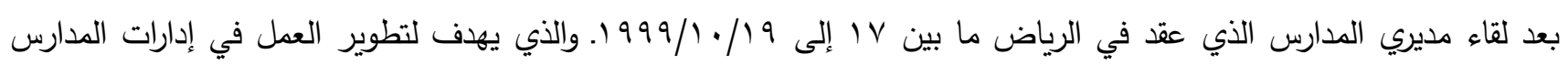

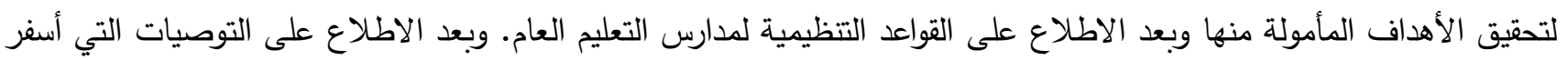

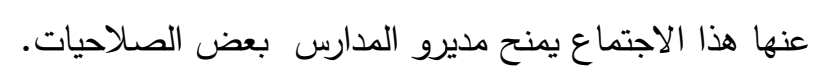
مفهوم الإدارة المدرسية:

تعتبر الإدارة المدرسية جزءًا من الإدارة التعليمية والفعل الإجرائي لها أي أن الإدارة المدرسية هي الكيفية التي ينجز بها العمل

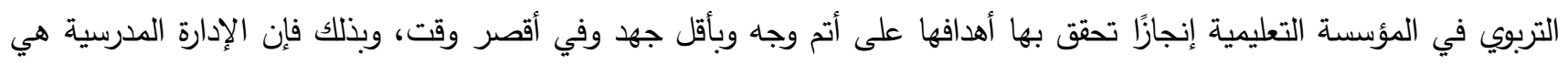
ليست كيانًا مستقلًا بل هي جزء من الإدارة التعليمية وصورة مصغرة لها، تتولى تتفيذ السياسة التعليمية بينما تتولى الإدارة التعليمية

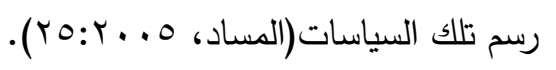

ويعرفها(حمودة) بأنها مجموعة من العمليات التي يقوم بها أكثر من فرد بطريق المشاركة والتعاون والفهم المتبادل من مدير المدرسة

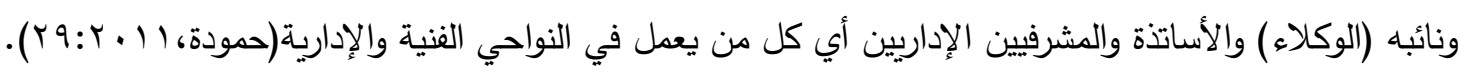

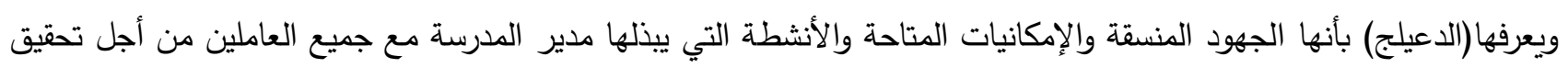

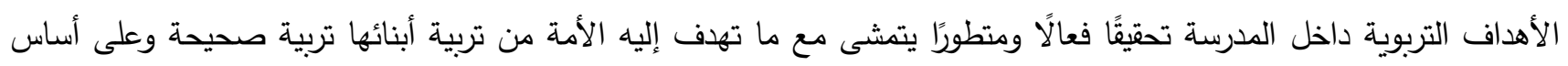

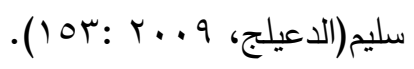

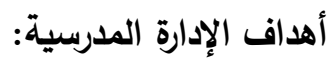

تتمثل أهداف الإدارة المدرسية في وضع خطط التطور والنمو المستقبلية للمدرسة، والإشراف التام على تتفيذ المعلمين للمناهج الدراسية والأنشطة غير المنهية، وكذلك الإشراف التام على تتفيذ مشاريع المدرسة حاضرًا ومستقبلا، وتحسين العلاقات بين المدرسة والبيئة الخارجية عن طريق مجالس الأباء وغيرها، وتوفير الأنشطة المدرسية المختلفة لنمو شخصية المتعلم، وتهيئة الجو

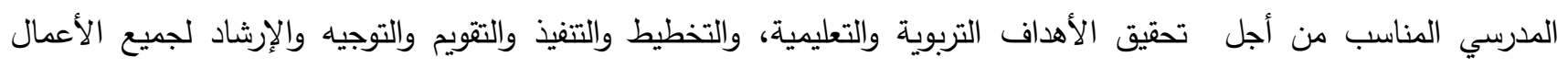

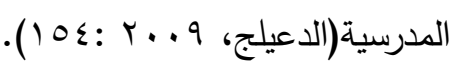

سمات مدير المدرسة :

يرى الإبراهيم(1) (1) أن من سمات المدير أن تكون شخصيته قيادية وجذابة ليستقطب إليه العاملين ولا ينفرهم. وأن يكون

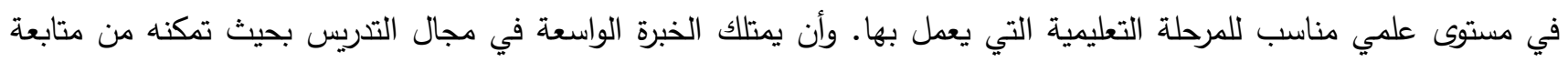
وتوجيه المعلمين، وكذلك أن يكون متعاونًا مع جميع العاملين بالمدرسة يتجنب التحيز لمجموعة دون أخرى، وأن يكون متفهمًا

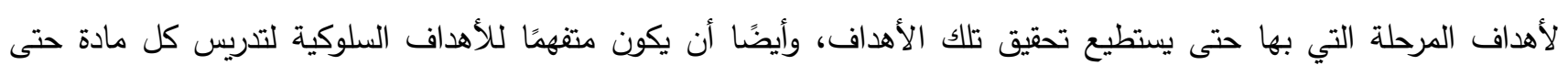

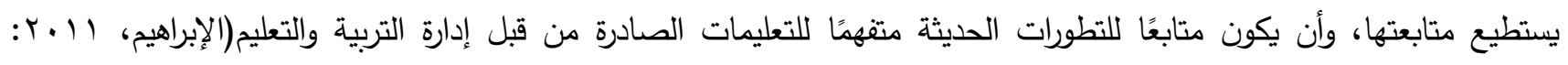

مفهوم التفويض: نظرًا لأهمية التفويض للمؤسسات التربوية فقد تتاوله العديد من العلماء والباحثين بالاهتمام الشديد من أجل توضيح معناه وتوضيح جزئياته ومجالاته، لذلك يرى الباحثان تعدد تعريف مفهوم التقويض وذلك تلبعًا للعلم الذي يتبعاته

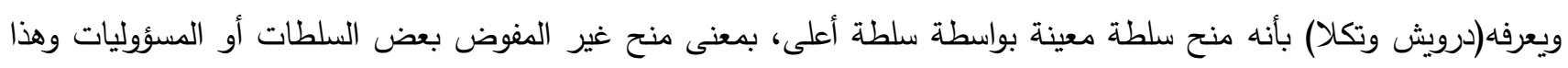

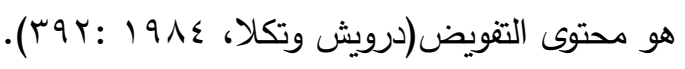


تعد الإدارة بالتقويض أحد أهم أدوات إدارة الوقت في المنظمات المختلفة، ولا غنى للقائد الفعال ولاسيما في المدارس من اللجوء إلى تفويض جزء من سلطاته أو بعض المهام إلى أحد معاونيه، ويعطيه سلطة اتخاذ القرارات اللازمة لتتفيذ المهام الموكلة إليه بعيدًا عن أية ضغوط أو قيود تحد من نشاطه الفكري وقدرته على الابتكار كما يعتبر التفويض من ناحية أخرى وسيلة للتمية

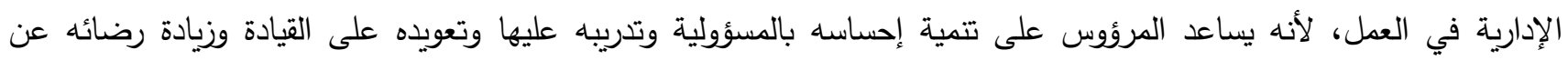

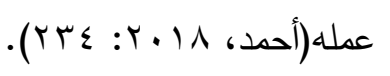

أهداف التفويض:

ا. الإصلاح الإداري: ويتوقف الإصلاح الإداري على حسن التخطيط وأسلوب جمع المعلومات وتحليلها وتفسيرها والقدرة على التقييم ومتابعة التتفيذ وأساليب القيادة والصلاحيات المخولة لكل مستوى من مستويات الإدارة(فليه وعبد المجيد،

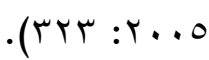

r. التطوير الإداري: إن التفويض يوفر للرؤساء الوقت الكافي للقيام بالمهام والأنشطة ذات الأولويـات العامـة المتصلة

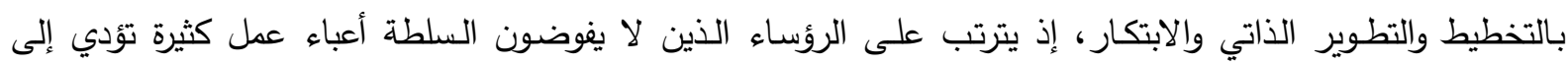

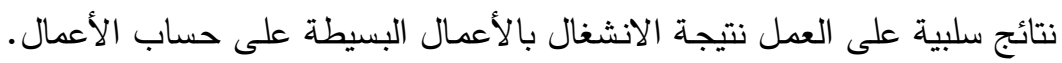

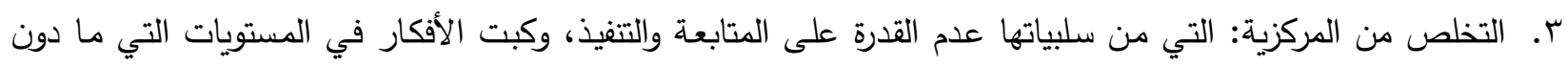

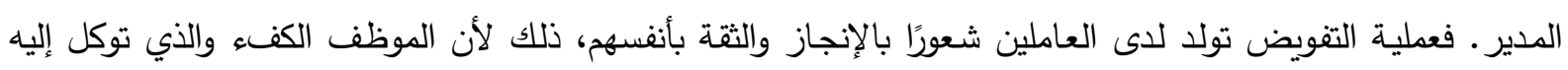

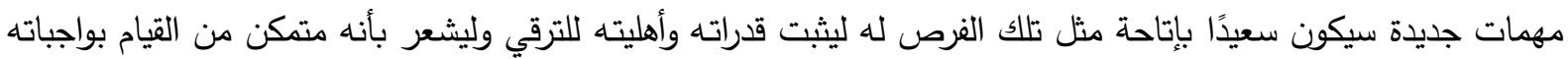

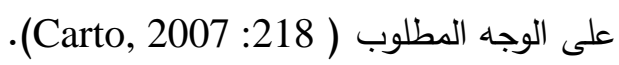
ع. الصحة التظيمية: تعتمد على أنجاز أهداف المؤسسة التربوية، وذلك يتطلب مشاركة العاملين بالمؤسسة في اتخاذ

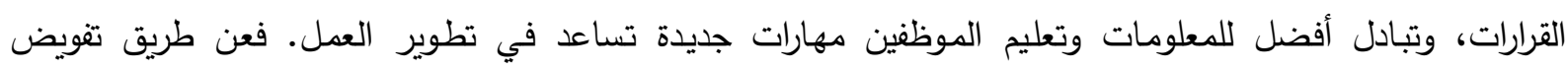
الصلاحيات يمكن تقديم خدمة للطلبة في المدرسة بشكل أفضل في كل الأوقات بحيث لا تتعطل الأمور في في غياب فئاب

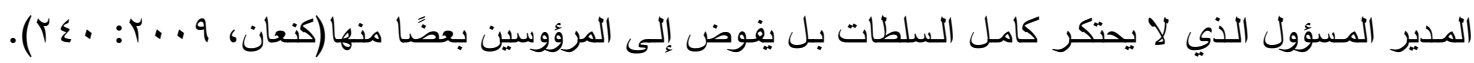
معوقات التفوبض:

على الرغم من أهمية التفويض ومزايـاه على مختلف المستويات إلا أن هنالك عددًا من العوامل والمشكلات والعقبات

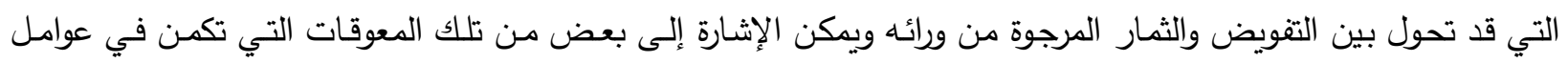
تتعلق بالمدير وعوامل متصلة بالوكلاء المفوضين. ويرى المعايطة(2007) أن صعوبات التفويض تتمثل في أن بعض العض المديرين

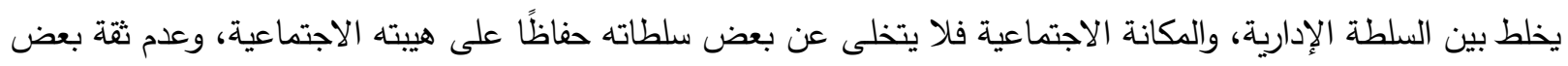
المديرين في قدرات مرؤوسيهج، وكذلك بقاء المدير مسؤولًا عن تصرفات مرؤوسيه بعد تفويض الصلاحيات لهم، وأيضًا سيطرة

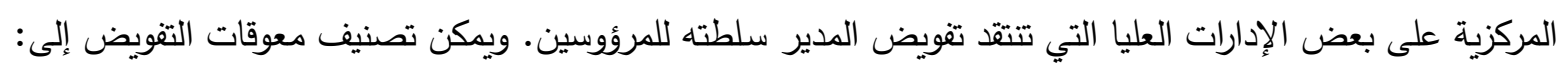

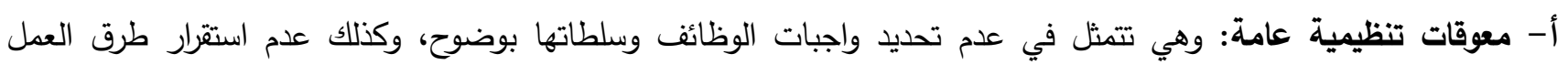

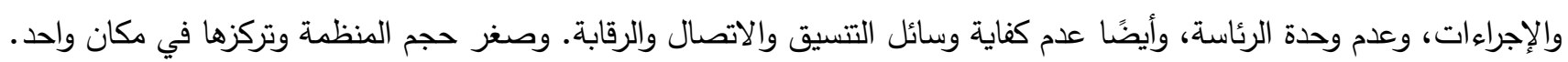

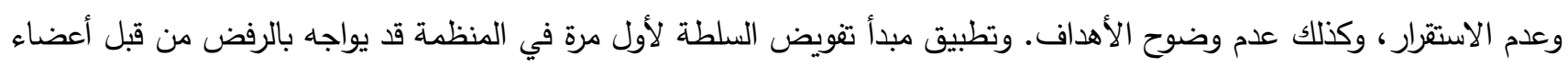

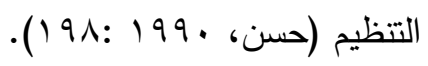
ب- معوقات تعود إلى المدير نفسه: وهي تتمثل في التعطش إلى السلطة، والاعتقاد السائد بأن التفويض يضعف النفوس، وكذلك

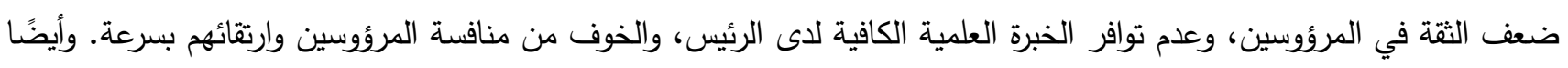

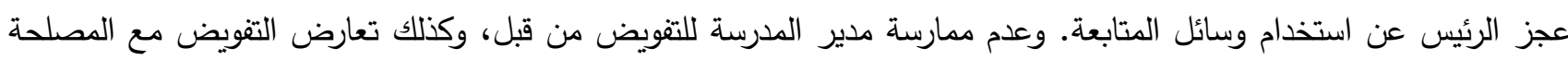

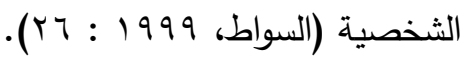




\section{مهام ومسؤوليات مدير المدرسة}

وتتحصر مسؤوليات المدير في الإحاطة الكاملة بأهداف المرحلة وتفهمها والتعرف على خصائص طلابها. وتهيئة البيئة التربوية الصالحة لبناء شخصية الطالب ونموه من جميع الجوانب، ومتابعة الإشراف على مرافق المدرسة وتجهيزاتها وتتظيمها

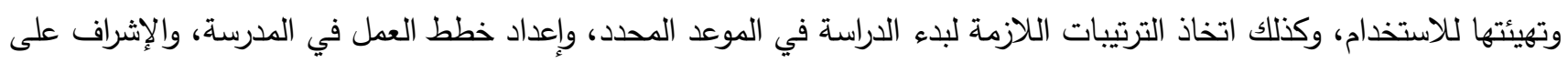
المعلمين وزيارتهم في الفصول، والاطلاع على أعمالهم ومشاركاتهم، وتقويم الأداء الوظيفي للعاملين في المدرسة وفقًا لتعليمات فئنة

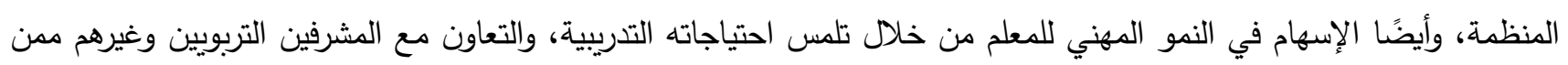

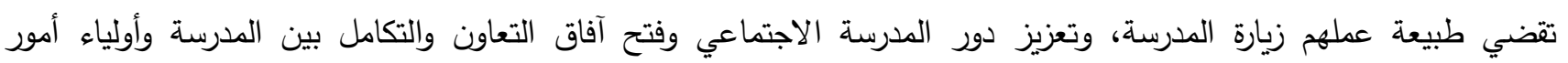

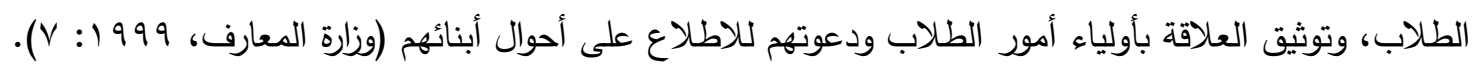

مسؤوليات وكيل المدرسة:

وتتمثل مسؤوليات وكيل المدرسة في الإشراف على قبول الطلاب وفحص وثائقهم وملفاتهم عند التسجيل أو التحويل. والإعداد

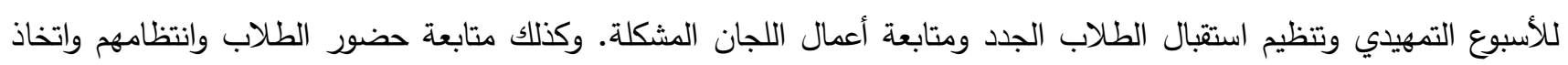
الإجراءات المناسبة في هذا الشأن.

وإعطاء الطلاب ما يحتاجون إليه من شهادات الانتماء للمدرسة، ومتابعة الحالات المرضية للطلاب بصفة عامة، والمعدية منها

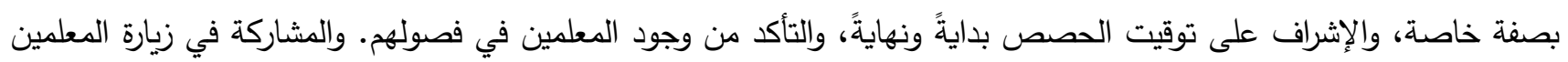

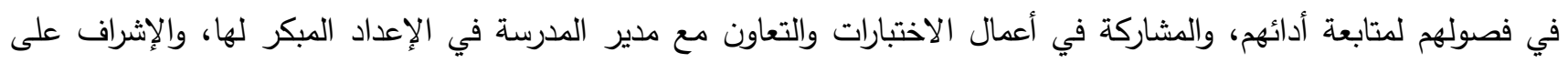
مرافق المدرسة ومتابعة المحافظة عليها وصيانتها، والمشاركة في المجالس واللجان بالمدرسة والإسهام في متابعة تتفيذ قراراتها،

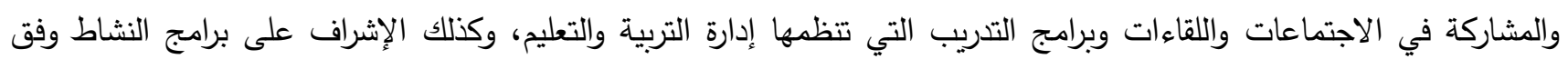
التتظيمات الخاصة به والمبلغة للمدرسة، وأيضًا متابعة حصول المدرسة على حاجاتها من الكتب الدراسية والمستلزمات الدراسية

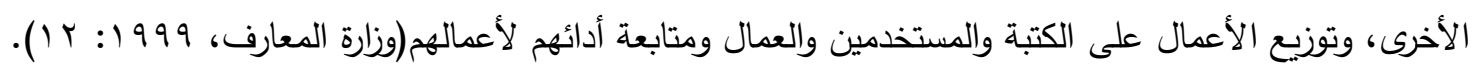

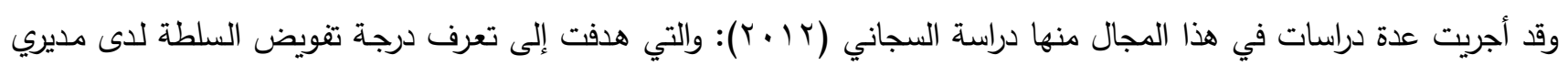
المدارس الثانوية بمحافظات غزة وعلاقتها بالرضا الوظيفي لاى معلميهم من وجهة نظرهم. استخدم الباحث المنهج الوصفي.

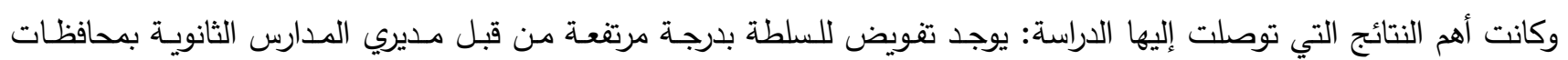

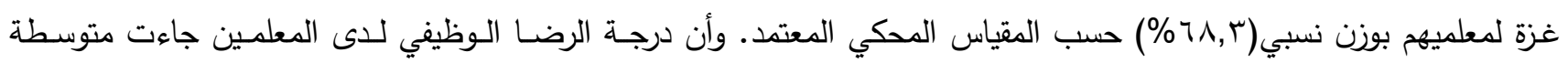

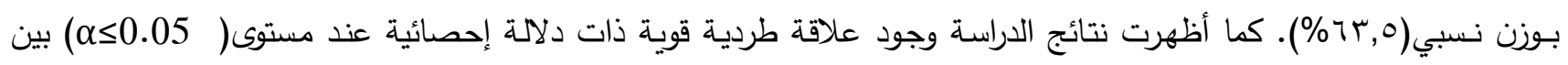

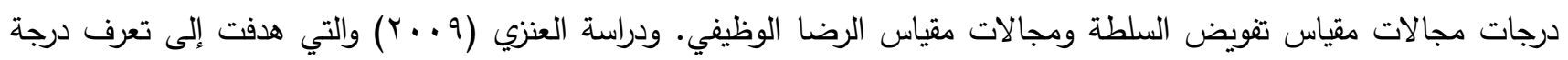

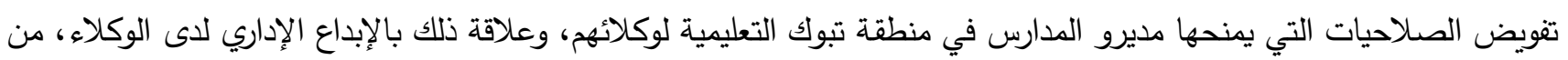

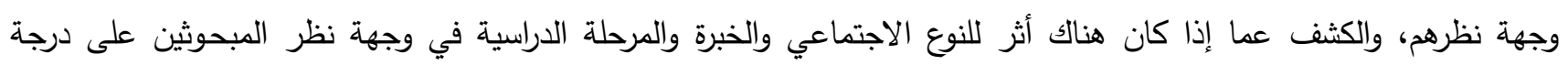
التفويض ودرجة الإبداع الإداري، استخدم الباحث المنهج الوصفي، وقد توصلت الدراسة إلى العديد من النتائج أهمها: وجود درجة مرتفعة من تفويض الصلاحيات الممنوحة لوكلاء المدارس. ويتوفر الإبداع الإداري بدرجة مرتفعة في مجال الخروج عن المألوف

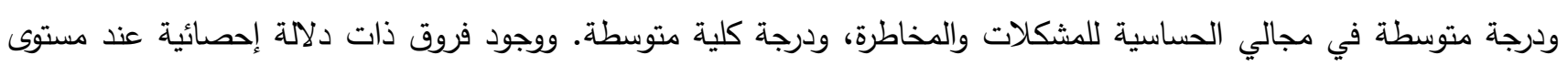

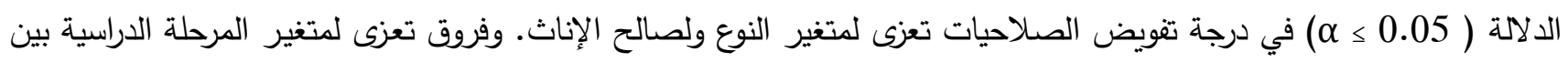

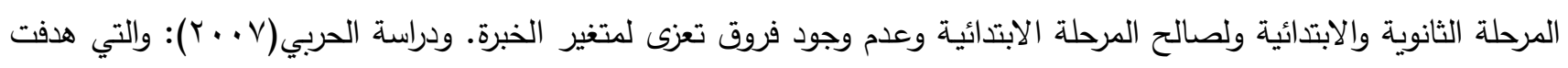

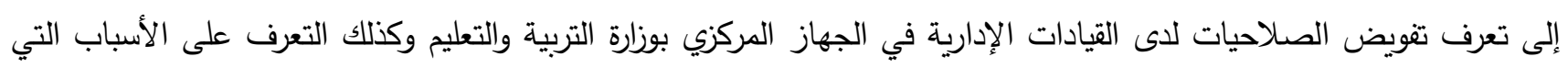

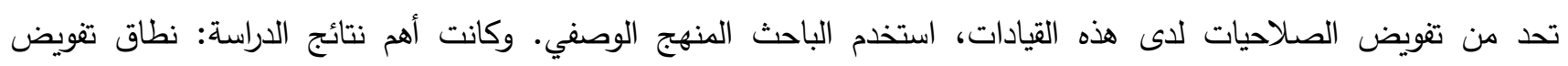

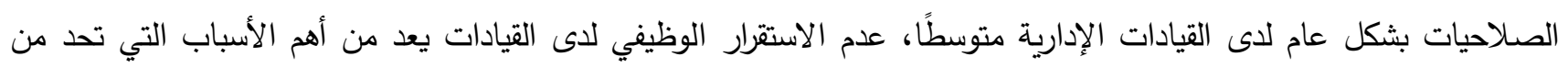

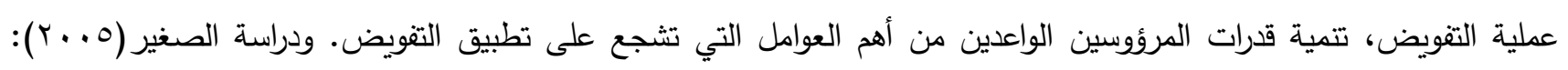
aे 1 | 1791 
والتي هدفت إلى تعرف واقع تفويض الصلاحيات لدى مديري الددارس الثانوية الحكومية بمدينة الرياض، استخدم الباحث المنهج

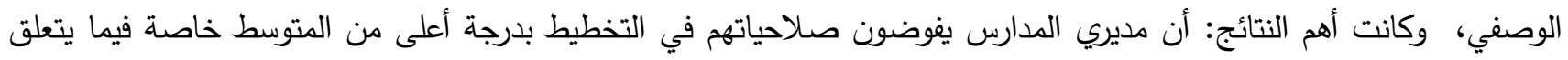
بإعداد جداول الانتظار والمناوبة والإشراف والحصص هذا بالإضافة إلى تفويض المعلمين في إعداد خطة قبول الطلاب واستيعابهم.

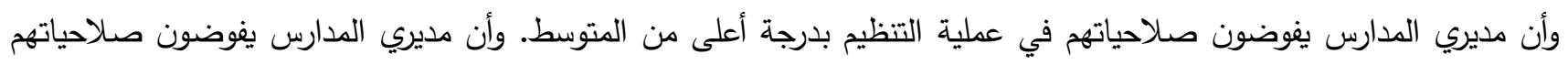

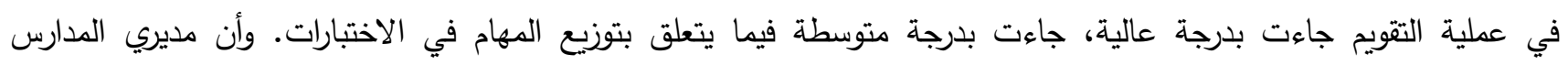

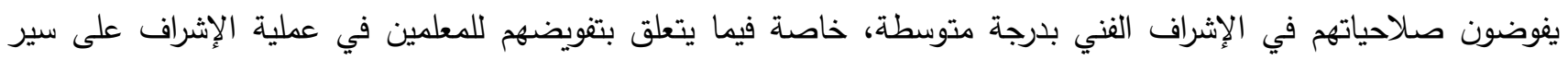

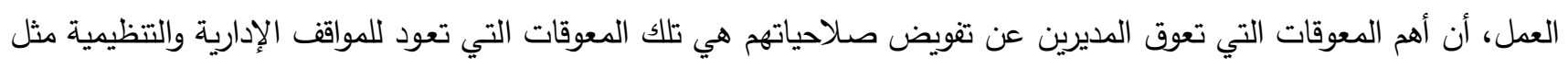
ضعف نظم الحوافز والتدريب والرقابة والإشراف الفني. ودراسة الشهري(r . r): والتي هدفت إلى تعرف واقع ممارسة مدير المدرسة

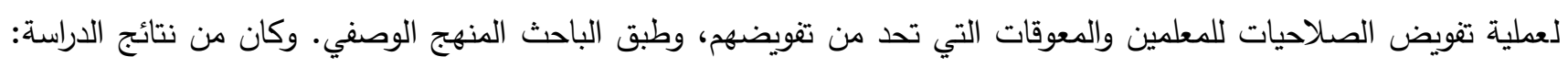

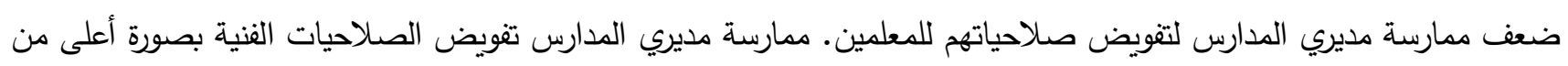

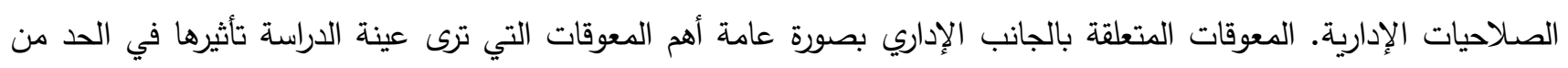

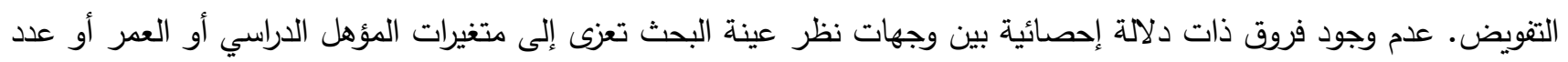
الطلاب أو المرحلة الدراسية. ودراسة تايلر (Taylor,1995): والتي هدفت إلى معرفة العوامل التي تسهل أو تعيق عملية التفويض.

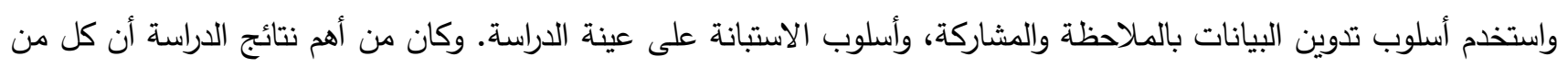

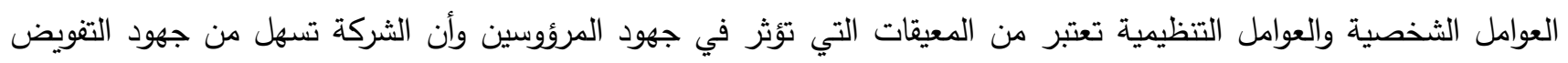
وضرورة دعم عملية التفويض بالمصادر المناسبة والتدريب اللازم للمديرين.

ويتضح من الدراسات السابقة اهتمامها بالكشف عن ممارسة مديري المدارس لتفويض الصلاحيات لوكلائهم من وجهة نظر

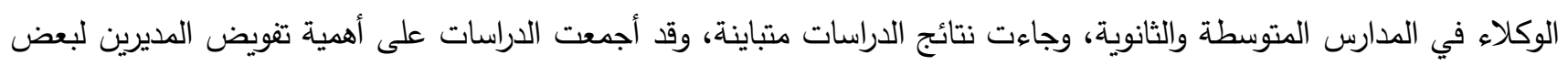

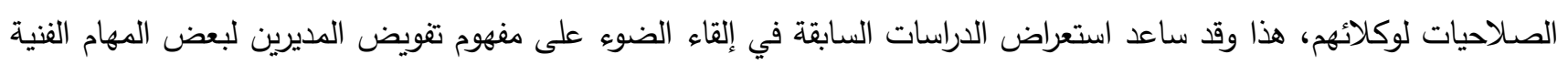
والإدارية لوكلائهم.

\section{مثكلة الاراسة وأسئلتها:}

تثهد الإدارة التربوية عامة والإدارة المدرسية خاصة العديد من التطورات والإصداحات التربوية في ظل مداخل إدارية عصرية كالجودة الشاملة والإدارة الاستراتيجية وإدارة المعرفة ويتطلب تفعيل هذه المداخل والمناحي العصرية الجديدة تطبيق عمليات وإجراءات إدارية حديثة أبرزها تفويض الصلاحيات من مدير المدرسة لساعده الأيمن وهو الوكيل، إلا إن الواقع الملموس يشهر مؤشرات بعيدة كل البعد عما هو المأمول وذلك من خلال خبرة الباحثين الثخصية. وكذلك ما يلاحظ في القصدور المتمثل في أداء

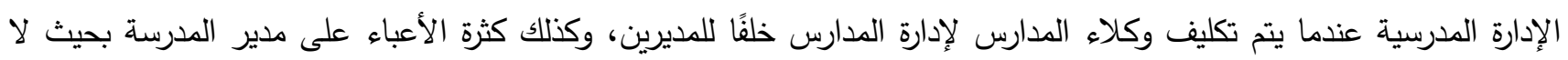

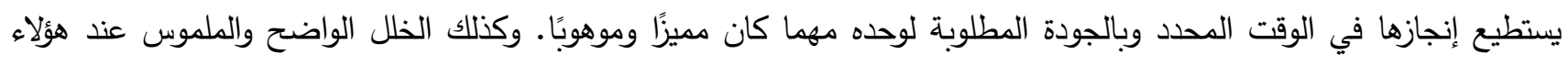

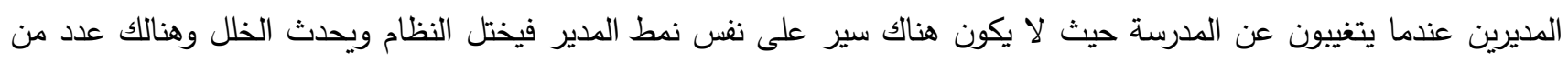

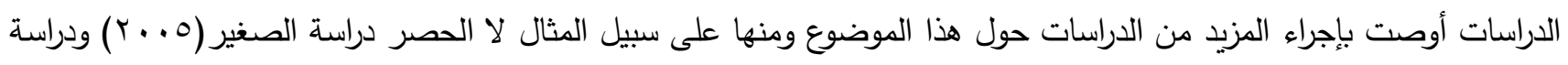

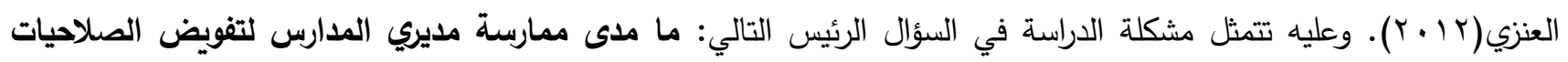
لوكلائهم من وجهة نظر الوكلاء في المدارس المتوسطة والثانوية بمحافظة الطائف؟ وتتفرع منه الأسئلة التالية:

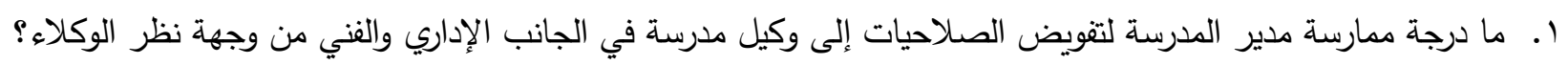

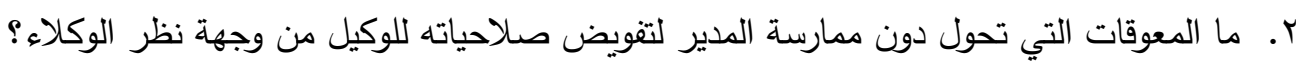


ا. . التعرف على درجة ممارسة مدير المدرسة لتفويض الصلاحيات إلى وكيل المدرسة في الجانب الإداري والفني من وجهة

نظر الوكلاء.

r. كثف المعوقات التي تحول دون ممارسة المدير لتفويض صلاحياته للوكيل من وجهة نظر الوكلاء.

أهمية الاراسة:

تتمثل أهمية هذه الدراسة في كثف العلاقة بين وكلاء المدارس ومديريها فيما يخص تفويض الصداحيات لوكلاء المدارس

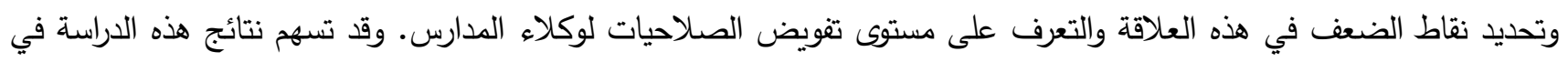
إثراء الأدب النظري الذي تناول موضوع تفويض صلاحيات مدير الددرسة حيث لاحظ الباحثان ندرة الدراسات العربية في هذا

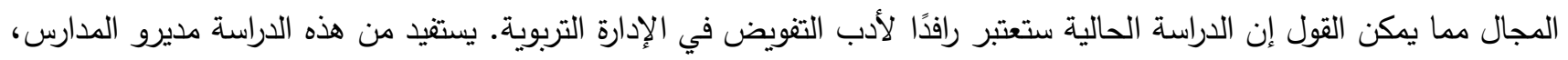

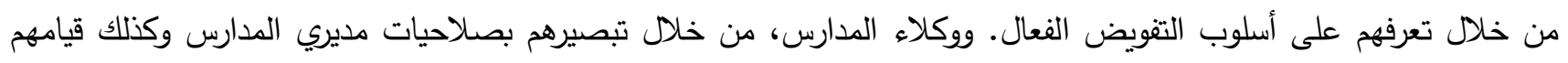
بأعمالهم على أكمل وجه، وبالتالي قدرتهم على قيادة المدرسة فيما بعد كمديرين في المستقبل. وإدارات التربية والتعليم، من خلال

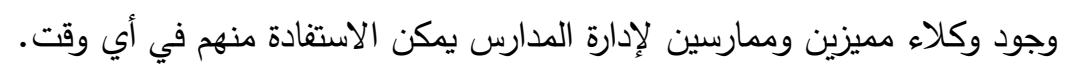

حدود الاراسة:

ا. ـ الحدود الموضوعية: تتمثل في مدى ممارسة مديري المدارس لتقويض الصدلاحيات لوكلائهم من وجهة نظر الوكلاء. r. الحدود البشرية: اقتصرت على وكلاء المدارس المتوسطة والثانوية بمحافظة الطائف.

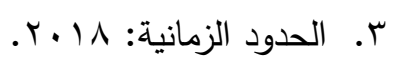

ـ. الحدود المكانية: المدارس المتوسطة والثانوية بمحافظة الطائف بالمملكة العربية السعودية.

مصطلحات الاراسة:

مفهوم الإدارة المدرسية: هي حصيلة العمليات التي يتم بواسطتها وضع الإمكانيات البشرية والمادية في خدمة أهداف عمل من

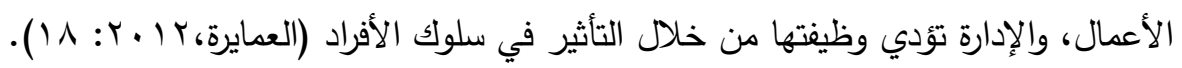
إجرائيًا: يقصد بها الباحثان إدارات مدارس التعليم المتوسط والثانوي بمحافظة الطائف.

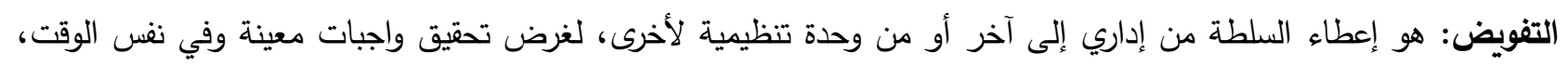

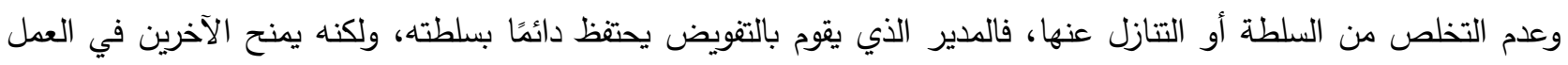

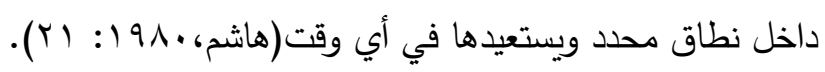

إجرائيًا: يقصد بها الباحثان تقويض مدير المدرسة لبعض الصدلاحيات الإدارية والفنية المتمثلة في التخطيط والتنظيم والإشراف الفني والتقويم. الصلاحيات: هي الصلاحيات المخولة للإداري والتي تتضمن حق إعطاء الأوامر والتوجيهات للمرؤوسين ووجوب الطاعة من

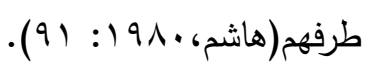
إجرائيًا: يقصد بها الباحثان الإمكانيات والحقوق الرسمية والتي بمقتضاها يستطيع المسؤول أداء العمل المطلوب منه وفقًا للخطة الموضوعة في مجال (التخطيط والتنظيم، والإشراف الفني، والتقويم). المعوقات: يقصد بها الباحثان في هذه الدراسة المعوقات التي تتعلق بالمدير والوكيل فقط. 
منهج الدراسة: استخدم الباحثان المنهج الوصفي، ويعتبر الدنهج الملاثم لهذه الدراسة.

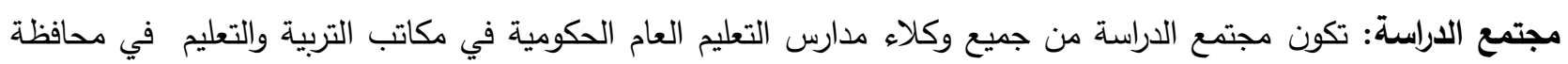

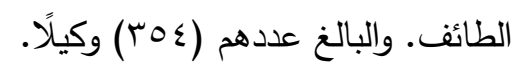
عينة الاراسة: تم اختيار عينة عشوائية بسيطة، من مجتمع الدراسة من وكلاء مدارس التعليم العام الدكومية في مكاتب التربية

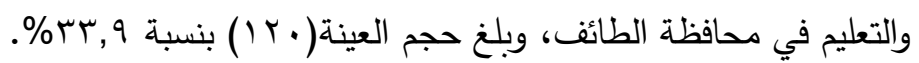

وصف عينة الاراسة:

جدول( ) يوضح الأعداد والنسب المئوية لأفراد عينة الدارسة وفقًا لمتفير المؤهل العلمي

\begin{tabular}{|c|c|c|}
\hline النسبة & العدد & المؤهل العلمي \\
\hline$\% 9$. & 1.1 & بكالوريوس \\
\hline$\%$ 1. & Ir & ماجستير \\
\hline$\% 1 \ldots$ & $1 r$. & المجموع الكلي \\
\hline
\end{tabular}

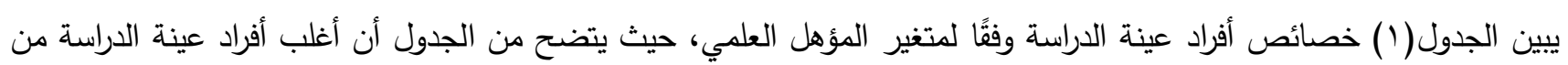

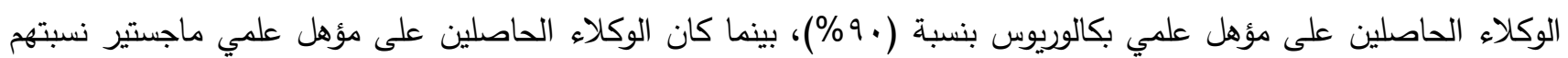

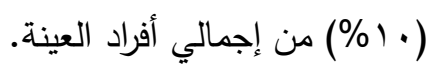

جدول(ץ) يوضح الأعداد والنسب المئوية لأفراد عينة الاراسة وفقًا لمتغير الخبرة في مجال العمل

\begin{tabular}{|c|c|c|}
\hline النسبة & العدد & الخبرة في مجال العمل \\
\hline \%ir,r & 17 & أقل من 0 سنوات \\
\hline$\% Y Y, 0$ & Tr & من ه إلى أقل من · ا سنوات \\
\hline$\% r q, r$ & ro & من · 1 إلى أقل من 10 سنة \\
\hline$\% r$. & $r 4$ & 10 سنة فأكثر \\
\hline$\% 1 \ldots$ & ir. & المجموع الكلي \\
\hline
\end{tabular}

يبين الجدول(r) خصائص أفراد عينة الدراسة وفقًا لمتغير الخبرة في مجال العمل، حيث يتضح من الجدول أن أغلب الوكلاء

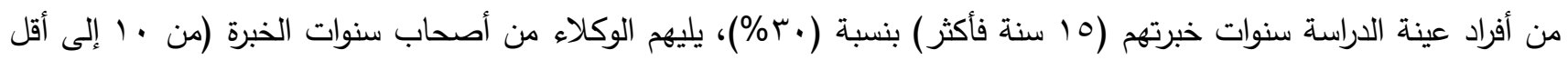

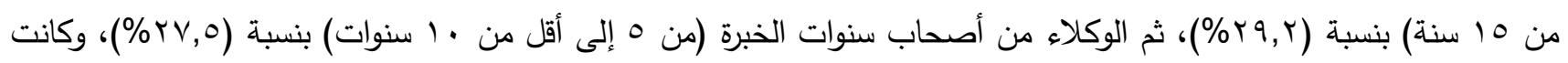

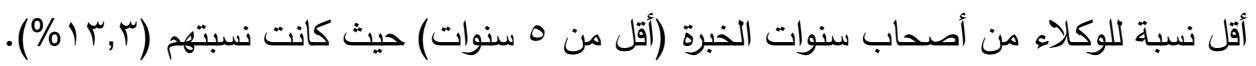

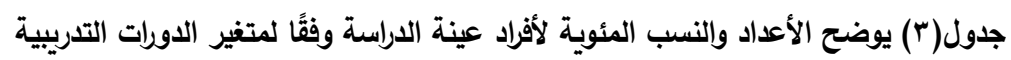

\begin{tabular}{|c|c|c|}
\hline النسبة & العدد & الدورات التدريبية \\
\hline$\% \varepsilon r, r$ & or & لا يوجد \\
\hline$\% r,, Y$ & $r 4$ & دورة واحدة \\
\hline$\% q, r$ & 11 & دورتان \\
\hline$\% r_{0, \Lambda}$ & $r$ & ثلاث دورات فأكثر \\
\hline$\% 1 \ldots$ & ir. & المجموع الكلي \\
\hline
\end{tabular}

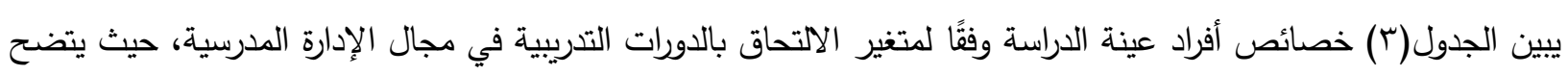

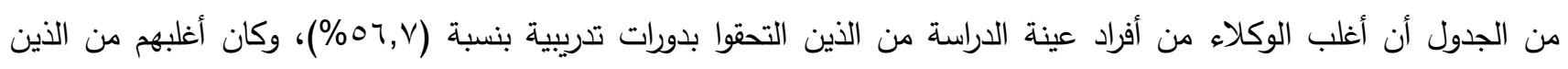

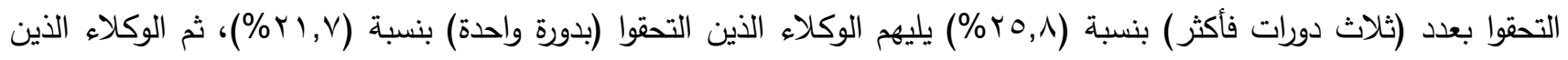

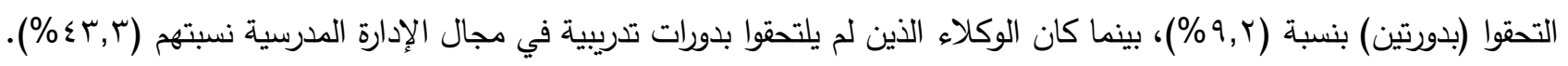


أداة الدراسة: على ضوء أهداف الدراسة وأسئلتها، تم استخدم الاستبانة كأداة لجمع المعلومات اللازمة للتعرف على مدى ممارسة

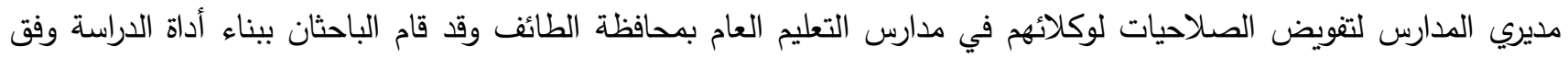

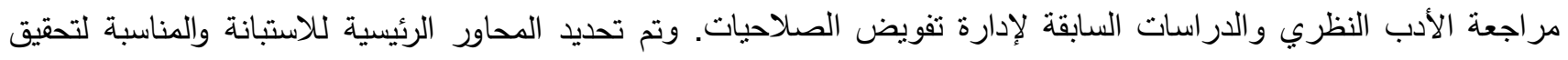

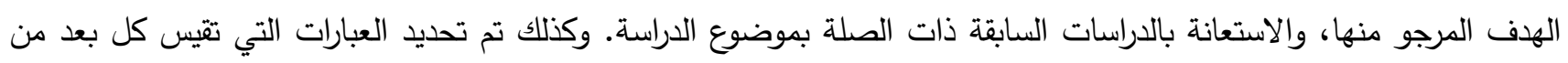
أبعاد الاستبانة. ومن ثم تم عرض الاستبانة على مجموعة من المحكمين من أعضاء هيئة التدريس في جامعة الملك عبد العزيز

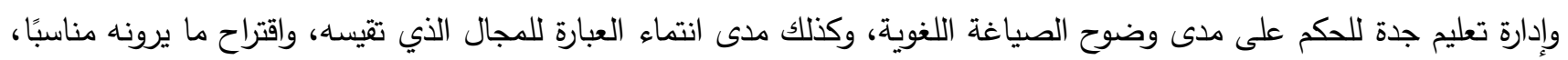

وبعد ذلك قام الباحثان بإجراء التعديل لبعض فقرات الاستبانة في ضوه آراء المحكمين وملاحظاتهم وإعادة ترتيب بعضها.

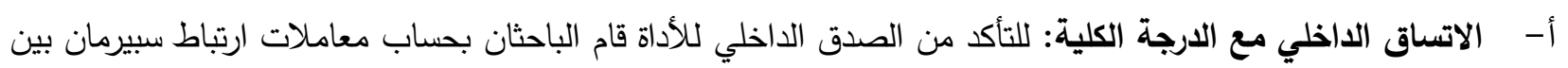

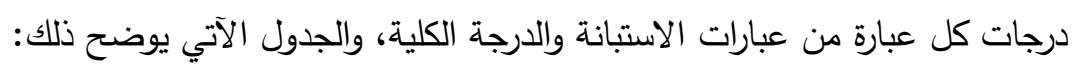

جدول(؛) يوضح معاملات ارتباط سبيرمان بين درجات كل عبارة مع الارجة الكلية

\begin{tabular}{|c|c|c|c|c|c|c|c|}
\hline معامل الارتباط & b & معامل الارتباط & 5 & معامل الارتباط & 5 & معامل الارتباط & b \\
\hline$* * \cdots, \wedge 1$. & rV & ***. & ro & $* * *, \wedge ץ \wedge$ & 14 & ***, & 1 \\
\hline$* *, \quad V \leq r$ & rᄉ & $* * *, \wedge \leq \varepsilon$ & $r y$ & $* *, \wedge, \uparrow$ & $1 \varepsilon$ & $* *, \vee \backslash r$ & $r$ \\
\hline$* *, \vee \wedge \wedge$ & rq & $* *, \vee \cdot \cdot$ & YV & $* * \%, 719$ & 10 & 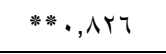 & $r$ \\
\hline$* *, \quad \vee 0 \leq$ & $\varepsilon$ & $* *, \quad, 1 \leq 7$ & $r \wedge$ & $* * \cdots, \neg \cdot \Lambda$ & 17 & $* *, \wedge \leq q$ & $\varepsilon$ \\
\hline$* * *, \wedge \leq Y$ & « & $* * *, \bigvee \backslash \wedge$ & rq & ***, V VTY & IV & ***, & 0 \\
\hline$* *, V T V$ & $\varepsilon r$ & $* *, Y, Y O V$ & $r$. & $* *, \vee \vee 9 \leq$ & 11 & $* *, \vee \vee \vee T$ & 7 \\
\hline$* *, \vee \wedge \wedge$ & $\varepsilon r$ & $* * \cdot \wedge r \mid$ & r & $* *, V \leq V$ & 19 & $* *, \wedge .0$ & V \\
\hline$* * \cdot \wedge 11$ & $\varepsilon \varepsilon$ & $* *, \wedge V Y$ & rr & $* *, V \leq r$ & $r$. & $* *, \wedge \cdot \Sigma$ & $\wedge$ \\
\hline$\% * \cdot, \wedge 9 r$ & $\leqslant 0$ & $\% * \cdot, \wedge 97$ & r & ***,人Tr & rI & 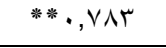 & 9 \\
\hline \multirow[t]{3}{*}{$* *, \wedge \uparrow \wedge$} & $\leq 7$ & ***, • NT & $r \varepsilon$ & $* *, \vee \wedge \wedge 1$ & rr & $* *, V \cdot \varepsilon$ & 1. \\
\hline & & 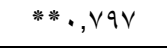 & ro & $* *, 719$ & rr & $* *, \vee \vee 9 r$ & 11 \\
\hline & & $* *, \vee \vee ० 0$ & די & $* *, V \cdot V$ & $r \varepsilon$ & *** & Ir \\
\hline
\end{tabular}

يتضح من الجدول(ع) أن معاملات ارتباط العبارات بالدرجة الكلية لمعاملات ارتباط سبيرمان بين درجات كل عبارة مع الدرجة

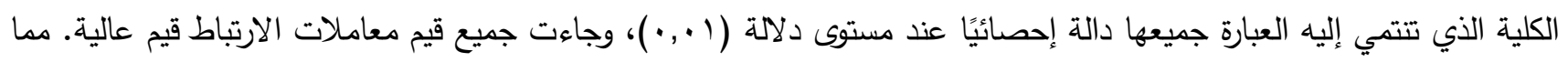
يدل على توافر درجة عالية من صدق الاتساق الداخلي للاستبانة.

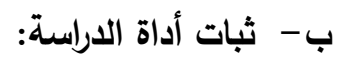

جدول(•) يوضح معاملات الثبات(ألفا كرونباخ) لمحاور الاستبانة والثبات الكلي للاستبانة

\begin{tabular}{|c|c|c|}
\hline معامل الثبات & عدد الفقرات & المحور \\
\hline \multicolumn{3}{|c|}{ لمحور الأول: مدى ممارسة مديري المدارس لتفويض الصلاحيات لوكلائهج } \\
\hline$\cdot, 9$. & $\mathrm{v}$ & لبعد الأول: التخطيط \\
\hline$\cdot, 9$. & 9 & لبعد الثاني: التنظيم \\
\hline$\cdot, \lambda \mathrm{V}$ & v & لبعد الثالث: الإثراف الفني \\
\hline$\cdot, \wedge r$ & 7 & لبعد الرابع: التقويم \\
\hline$\cdot, 90$ & rq & الثبات الكلي للمحور الأول \\
\hline \multicolumn{3}{|c|}{ المحور الثاني: معوقات تفويض الصلاحيات لاى مديري المدارس لوكلائهم } \\
\hline$\cdot, 9 \leq$ & 9 & لبعد الأول: معوقات تعود لمدير المدرسة \\
\hline$\cdot, 94$ & $\Lambda$ & لبعد الثاني: معوقات تعود للوكلاء \\
\hline$\cdot, 94$ & 1. & لبعد الثالث: معوقات تعود للمواقف الإدارية والتظظيمية \\
\hline., 95 & tr & الثبات الكلي للمحور الثاني \\
\hline., 91 & 04 & الثبات الكلي للاستبانة \\
\hline
\end{tabular}

* * دال إحصائيًا عند مستوى دلالة ا., ,. 
يبين الجدول(0) أن جميع قيم معاملات الثبات لمحاور الاستبانة كانت قيم عالية حيث بلغت قيمة معامل الثبات الكلي للمحور

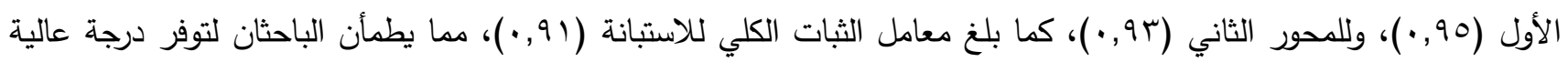

من الثبات للاستبانة.

الأساليب الإحصائية المستخدمة: بناءً على طبيعة الدراسة والأهداف التي سعت إلى تحقيقها، تّمّ تحليل بياناتها باستخدام برنامج

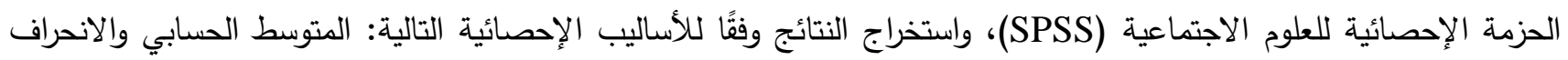
المعياري. ومعامل ارتباط بيرسون لحساب الاتساق الداخلي. ومعامل الثبات بطريقة ألفا كرونباخ.

\section{نتائج الاراسة ومناقشتها:}

قام الباحثان بحساب المدى لمستويات المقياس وهو = 0 ، وبتقسيم المدى على عدد مستويات المقياس الذي يساوي ه ، كان ناتج القسمة = . ^, · وهو يمثل طول الفئة، وبذلك أصبحت معايير مفتاح التصحيح للمقياس على النحو التالي:

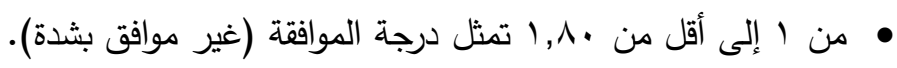

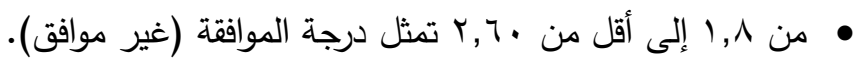

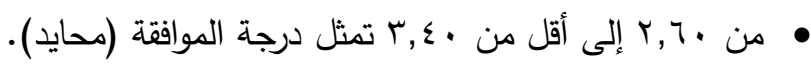

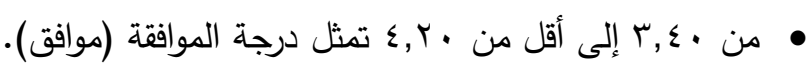

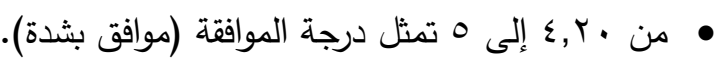

ومن ثم تم عرض وترتيب النتائج الخاصة بأسئلة الدراسة وفقًا للمتوسطات الحسابية والانحراف المعياري، وسوف يتم الإجابة

عن الأسئلة بترتيب ما جاءت في الإطار النظري.

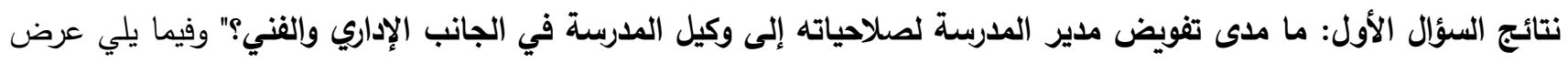
تفصيلي لأبعاد مدى ممارسة مديري المدارس لتفويض الصلاحيات لوكلائهم من وجهة نظر وكلاء مدارس التعليم العام الحكومية

بمحافظة الطائف، وهي:

1. البعد الأول: مدى ممارسة مديري المدارس لتفويض الصلاحيات لوكلائهم في التخطيط.

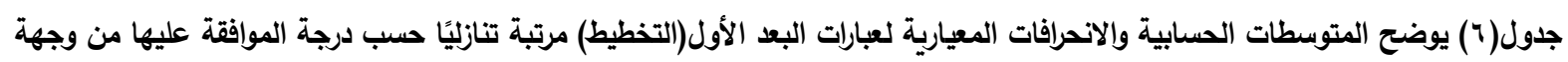

نظر وكلاء مدارس التعليم العام الحكومية بمحافظة الطائف.

\begin{tabular}{|c|c|c|c|c|}
\hline درجة الموافقة & الانحرافي & الحسابي & 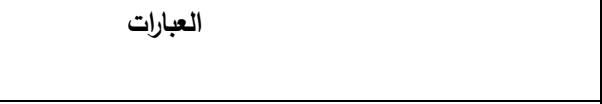 & r \\
\hline 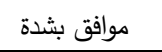 & $\cdot, \wedge \Lambda t$ & $\varepsilon, r_{0}$ & | إعداد جدول الانتظار للمعلمين & 1 \\
\hline موافق بشدة & $\cdot, \wedge \wedge \varepsilon$ & $\varepsilon, r \mu$ & إعداد خطة قبول الطلاب واستيعابهم & $r$ \\
\hline 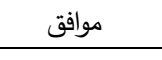 & $\cdot, \wedge 91$ & $\varepsilon, 1 Y$ & إعداد جدول المناوبة لدخول الطلاب وخروجهم من الددرسة & r \\
\hline 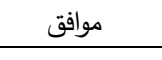 & $1, \cdot \Lambda$ & $\varepsilon, \cdot r$ & إعداد جدول الإشراف اليومي للمعلمين & $\varepsilon$ \\
\hline 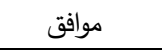 & $1, \cdot v r$ & r,qv & | إعداد جداول الحصص الددرسية & $\circ$ \\
\hline 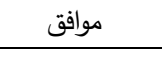 & $1, \cdot r \cdot$ & $r, v r$ & تحديد مواعيد الاختبارات نصف الفصلية & 7 \\
\hline 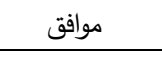 & $1, .07$ & $r, \varepsilon \cdot$ & تحديد مواعيد الاجتماعات في الددرسة & $\mathrm{v}$ \\
\hline 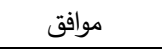 & $\cdot, 7 \wedge 9$ & $r, 97$ & 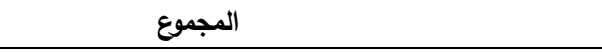 & \\
\hline
\end{tabular}

يتضح من الجدول(؟) أن مدى ممارسة مديري المدارس لتفويض الصلاحيات لوكلائهم في التخطيط جاء بدرجة موافقة

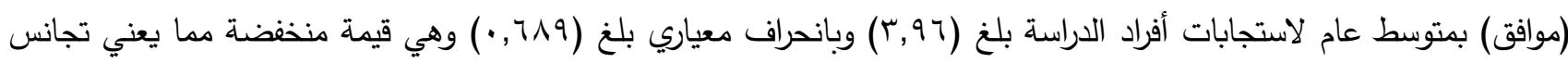

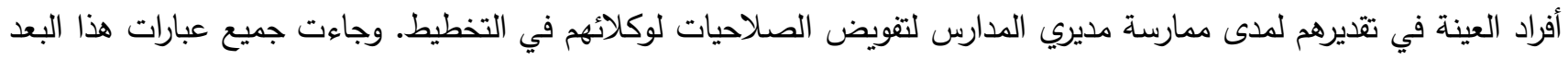
بدرجة موافقة (موافق)، فيما عدا العبارتين إعداد جدول الانتظار للمعلمين وإعداد خطة قبول الطلاب واستيعابهم اللتين جاءتا في

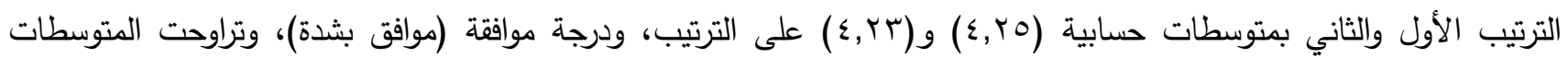




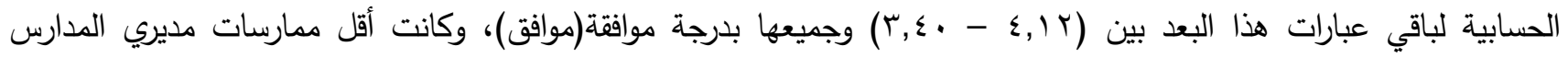
لتفويض الصلاحيات لوكلائهم في التخطيط هي تحديد مواعيد الاجتماعات في المدرسة حيث جاءت في الترتيب الأخير بدرجة

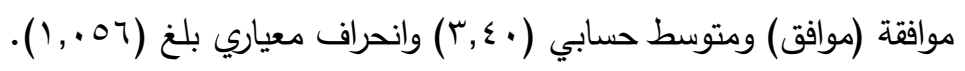

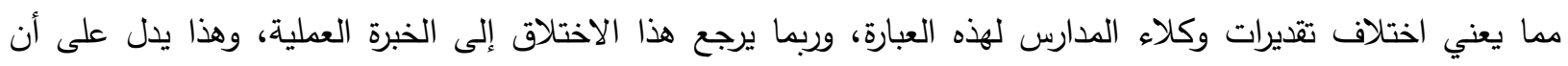

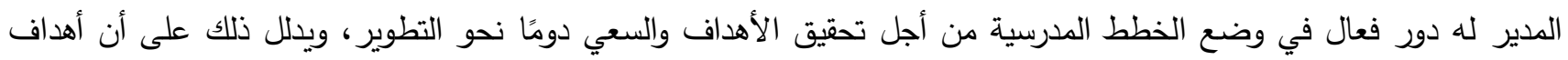
المدرسة بالنسبة إليه واضحة وكذلك يمتلك الكيفية الصحيحة لتحقيقها. لذلك جاءت ممارسة درجة تفويض التخطيط بدرجة(موافق) أي أعلى من المتوسط وتتفق هذه النتيجة مع توصل إليه الصغير (0 . ب ) في دراسته حيث أشار إلى أن مديري المدارس يفوضون

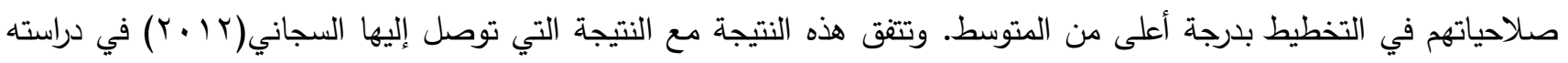
حيث أشار إلى أنه يوجد تفويض للسلطة بدرجة مرتفعة من قبل مديري المدارس الثانويـة بمحافظـات غزة لمعلميهم. r. البعد الثاني: مدى ممارسة مديري المدارس لتفويض الصلاحيات لوكلائهم في التنظيم.

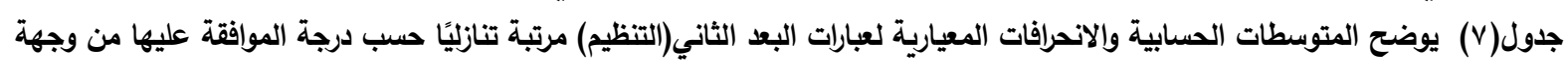
نظر وكلاء مدارس التعليم العام الحكومية بمحافظة الطائف.

\begin{tabular}{|c|c|c|c|c|}
\hline الموافقة & المعياري & الحسابوسط & 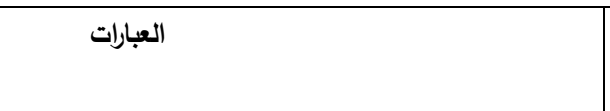 & P \\
\hline 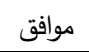 & $1, \cdot \times 9$ & r, १६ & | منح العاملين خطابات تعريف وففًا للنظام & 1 \\
\hline 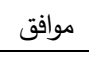 & $1, \cdots 9$ & $r, q r$ & |قبول الطلاب في الددرسة & $r$ \\
\hline موافق & $1, \cdot r 4$ & $r, \uparrow \Lambda$ & | تشكيل اللجان المطلوبة لتنظيم العمل & $r$ \\
\hline موافق & $1, \cdot \times 9$ & $r, r)$ & |توزيع غرف المبنى المدرسي ليتناسب مع الطلاب والعاملين & $\varepsilon$ \\
\hline 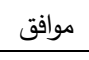 & $1,1 v 1$ & $r, 0 \wedge$ & | توزيع المهام على العاملين في الددرسة & $\circ$ \\
\hline موافق & $1,1 \cdot v$ & $r, 0 \varepsilon$ & | تشكيل المجالس المدرسية & 7 \\
\hline محايد & $1, r+\wedge$ & $r, \cdot \Lambda$ & | منح الإجازات المرضية للعاملين وفقًا للنظام & v \\
\hline 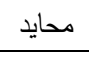 & $1, r \leqslant 9$ & $r, 90$ & | منح الإجازات الاضطرارية للعاملين & $\wedge$ \\
\hline محايد & 1,171 & $r, 7 \Lambda$ & | تحديد المعلم الزائد وفقًا النظام & 9 \\
\hline 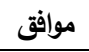 & $\cdot, \vee \wedge \varepsilon$ & $r, \varepsilon$ ๕ & 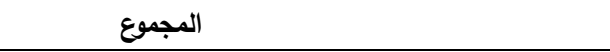 & \\
\hline
\end{tabular}

يتضح من الجدول(V) أن مدى ممارسة مديري المدارس لتفويض الصلاحيات لوكلائهم في التتظيم جاء بدرجة موافقة

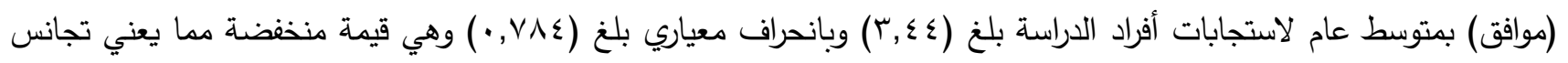

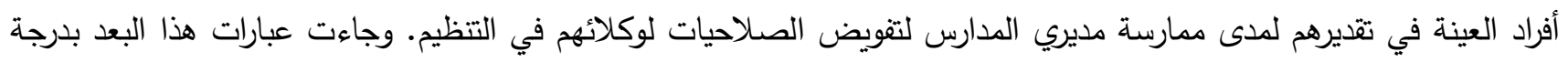

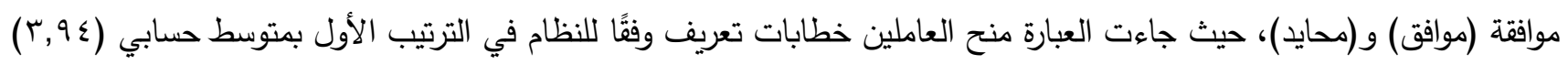
يليها في الترتيب الثاني قبول الطلاب في المدرسة بمتوسط حسابي (r, (؟)، وكلاهما بدرجة موافقة (موافق)، وتراوحت المتوسطات

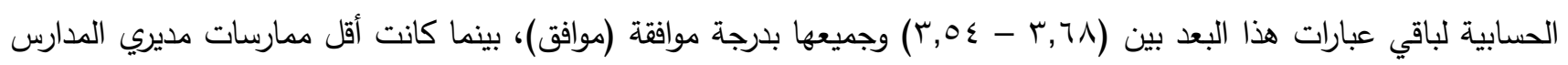

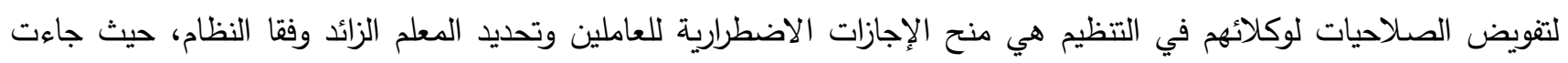

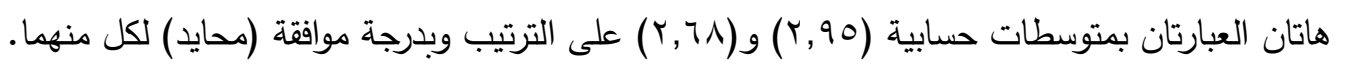

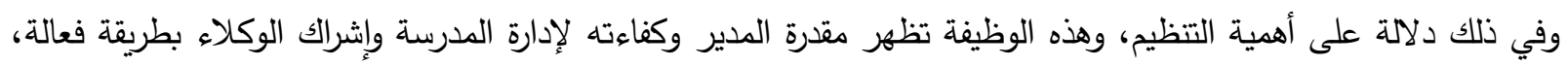
لذلك تحتاج وظيفة التظيم إلى مقدرة إدارية عالية من قبل الميرين والوكلاء، وهذه النتيجة جاءت بدرجة ممارسة أعلى من المتوسط لألى

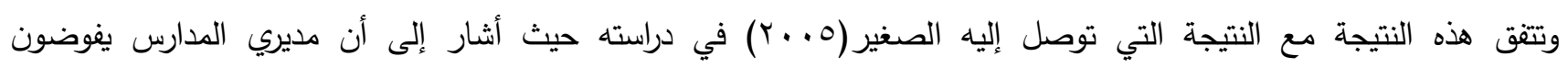
صلاحياتهم في عملية التتظيم بدرجة أعلى من المتوسط. r. البعد الثالث: مدى ممارسة مديري المدارس لتفويض الصلاحيات لوكلائهم في الإثراف الفني. 
جدول(^) يوضح المتوسطات الحسابية والاتحرافات المعيارية لعبارات البعد الثالث(الإشراف الفني) مرتبة تنازئًا حسب درجة الموافقة عليها من وجهة نظر وكلاء مدارس التعليم العام الحكومية بمحافظة الطائف.

\begin{tabular}{|c|c|c|c|c|}
\hline درجة الموافقة & الانحراف المعياري & الحسابي & 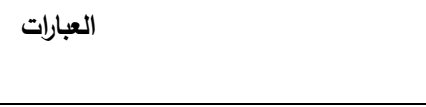 & r \\
\hline موافق بشدة & $\cdot, \vee \cdot q$ & $\varepsilon, \Sigma\rceil$ & الإثراف على سير العمل داخل المدرسة & 1 \\
\hline 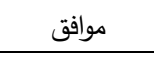 & $\cdot, 9 \vee \leq$ & $r, 99$ & زيارة المعلمين في الفصول & r \\
\hline 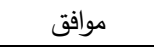 & $\cdot, 941$ & r,q^ & متابعة تبادل الزيارات بين المعلمين & r \\
\hline 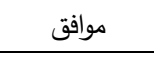 & $1, \cdot 41$ & $\curlyvee, \wedge \varepsilon$ & الاطلاع على دفاتر المتابعة لدى المعلمين & $\varepsilon$ \\
\hline 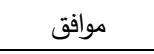 & $1,1 K r$ & $r, v r$ & الاطلاع على دفاتر تحضير المعلمين & $\circ$ \\
\hline 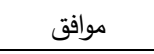 & $1,1 \cdot 1$ & $r, \uparrow \Lambda$ & متابعة ملاحظات المشرفين مع المعلمين & 1 \\
\hline 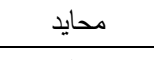 & $1, \cdot 7 r$ & $r, r q$ & اقتراح برامج النمو المهني للمعلمين & V \\
\hline موافق & $\cdot, \mathrm{V} \leqslant 0$ & $r, \wedge \vee$ & 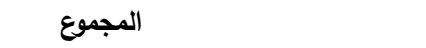 & \\
\hline
\end{tabular}

يتضح من الجدول(^) أن مدى ممارسة مديري المدارس لتفويض الصلاحيات لوكلائهم في الإشراف الفني جاء بدرجة

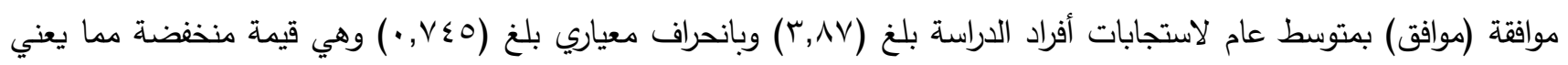

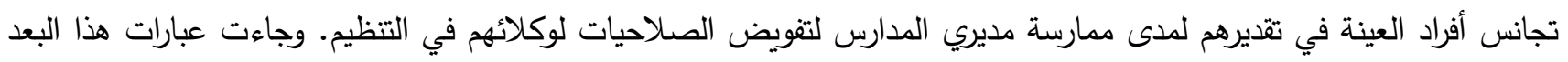
بدرجة موافقة (موافق بشدة) و (موافق) و(محايد)، حيث جاءت العبارة الإشراف على سير العمل داخل المدرسة، في الترتيب الأول

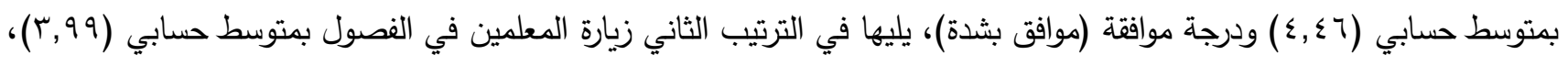

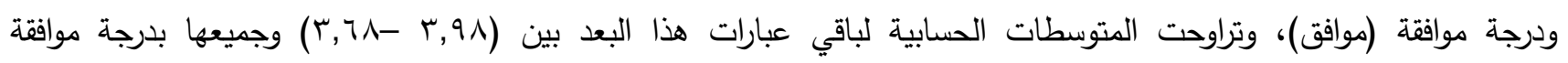
(موافق)، بينما كانت أقل ممارسات مديري المدارس لتفويض الصدلاحيات لوكلائهم في الإشراف الفني هي اقتراح برامج النمو المهني

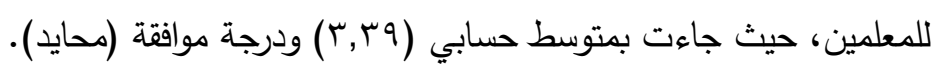
وهذا يدل على أن معظم المديرين يحرصون على سير العمل داخل المدرسة بالصورة المطلوبة، ولكن هنالك قصورًا في برامج

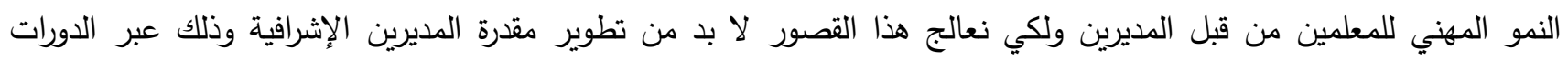

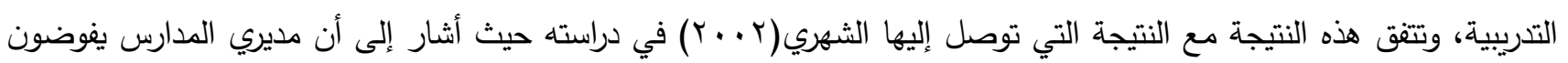
صلاحياتهم في الإشراف الفني بدرجة متوسطة، واختلفت هذه النتيجة مع النتيجة التي توصل إليها الصغير في دراسته ديث ديث أشار إلى أن هنالك ضعف في نظام الحوافز والتدريب والرقابة والإشراف الفني وربما يرجع هذا الاختلاف لطبيعة المجتمع التي أجريت فيه

ع. البعد الرابع: مدى ممارسة مديري المدارس لتفويض الصلاحيات لوكلائهم في التقويم.

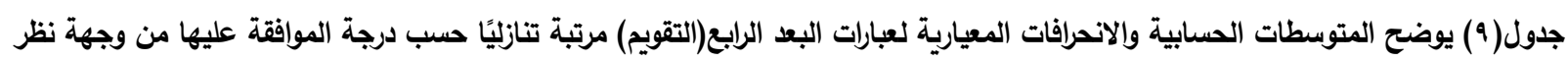
وكلاء مدارس التعليم العام الحكومية بمحافظة الطائف.

\begin{tabular}{|c|c|c|c|c|}
\hline الموافقة & المعياري & الكسابوسط & 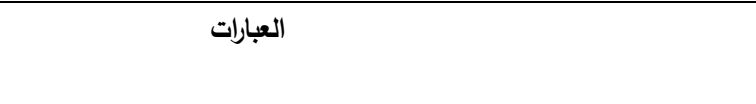 & p \\
\hline 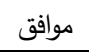 & $1, \cdot 10$ & $r, \wedge т$ & توزيع الدهام في الاختبارات & 1 \\
\hline 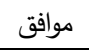 & $1,1 \vee \wedge$ & $r, v \cdot$ & تكليف المعلمين بوضع أسئلة مواد الاختبارات في تخصصهم & r \\
\hline 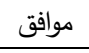 & $1,1 \pi$ & $r, \uparrow$ & إعادة اختبار بعض الطلاب إذا ثبت أنه تم اختبارهم في ظروف غير ملائمة & $r$ \\
\hline محايد & $1, r 17$ & $r, r \wedge$ & إعداد تقارير الكفاية للمعلمين & $\varepsilon$ \\
\hline 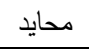 & $1,1 \leq 7$ & $r, r r$ & إعداد تقارير الكفاية لعاملين في المدرسة غير المعلمين & ${ }^{\circ}$ \\
\hline 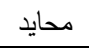 & $1, r \cdot r$ & $r, r)$ & توجيه خطابات لفت النظر للعاملين المقصرين & T \\
\hline موافق & $\cdot, \wedge \wedge 0$ & $r, \leqslant \wedge$ & 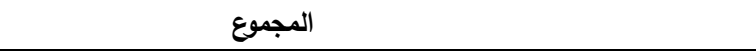 & \\
\hline
\end{tabular}


يتضح من الجدول(9) أن مدى ممارسة مديري المدارس لتقويض الصلاحيات لوكلائهم في التقويم جاء بدرجة موافقة

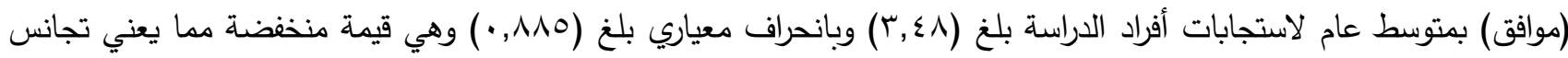
أفراد العينة في تقديرهم لمدى ممارسة مديري المدارس لتقويض الصدلاحيات لوكلائهم في التنظيم. وجاءت عبارات هذات التهات البعد بدرجة

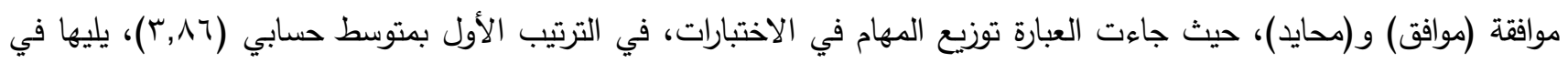

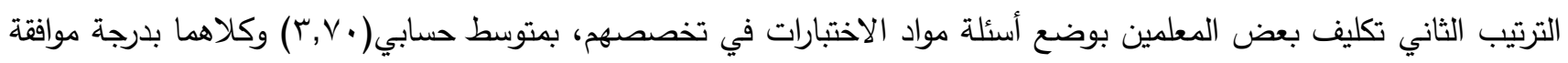

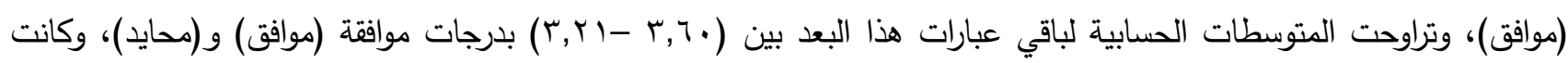

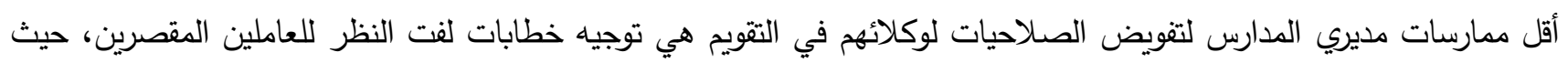
جاءت هذه العبارة بمتوسط حسابي (I,Y, (r) ودرجة موافقة (محايد). وهذه النتيجة تبرز أهمية عملية التقويض في مجال التقويم، ويعتبر التقويم أهم وظائف الإدارة ويدل ذلك على ودئ أن مدير المدرسة يتقن وظيفة التقويم ويشرك فيها الوكلاء ولكن ليس بالقدر الكافي وتتقق هذه النتيجة مع النتيجة التي توصل إليها

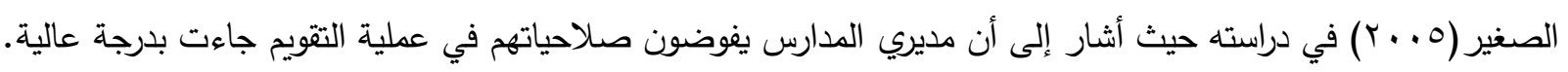

نتائج السؤال الثاني: ما المعوقات التي تحول دون ممارسة المدير لتفويض صلاحياته للوكيل من وجهة نظر الوكلاء؟ وفيما يلي عرض تفصيلي لمعوقات تفويض الصداحيات لدى مديري الددارس لوكلائهم من وجهة نظر وكلاء مدارس التعليم العام

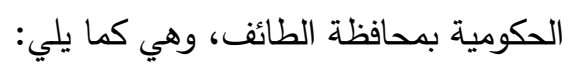

ا. . معوقات تفويض الصلاحيات لاى مديري المدارس لوكلائهم والتي تعود لمدير المدرسة.

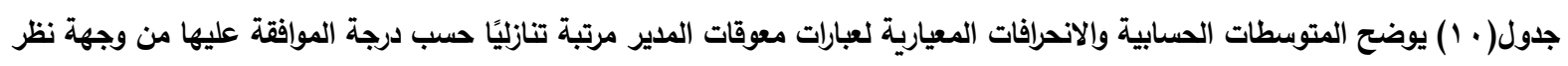
وكلاء مدارس التعليم العام المكومية بمحافظة الطائف.

\begin{tabular}{|c|c|c|c|c|}
\hline درجة الموافقة & الانعراف & الحستوسط المسي & 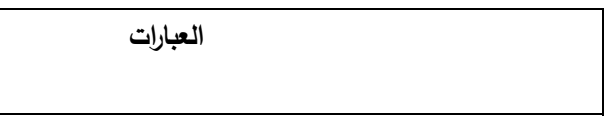 & b \\
\hline 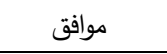 & 1,101 & $r, T \leqslant$ & قلة وجود صلاحيات زائدة لاى المدير ليفوضها & 1 \\
\hline 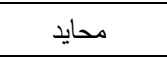 & $1,1 \pi r$ & $r, r q$ & خوف بعض المديرين من تحمل أخطاء الآخرين & r \\
\hline محايد & $1,|1|$ & $r, r \varepsilon$ & يعتبر المدير تفويض الصلاحيات إهدارًا للوقت والجهـ & r \\
\hline محايد & $1, r r \varepsilon$ & $r, \cdot \Lambda$ & قلة فهم بعض مديري المدارس لمهامهم ومسؤولياتهم & $\varepsilon$ \\
\hline 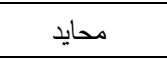 & I,HYT & $r, r$ & الرغبة في تركيز السلطة للظهور بمظهر القوة & $\circ$ \\
\hline 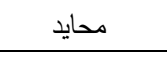 & $1, r 74$ & r, 97 & الخوف من زيادة نفوذ الوكيل ومنافسته للمدير & 7 \\
\hline محايد & 1,114 & r,q4 & ضعف ثقة المير في كفاءة الوكلاء & 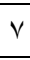 \\
\hline 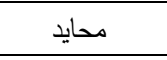 & $1,1 V r$ & $r, \wedge \mathrm{V}$ & الخوف من تأثير التفويض على تقييم الأداء الوظيفي للمدير & $\wedge$ \\
\hline 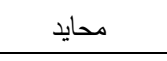 & $1, r \leq 0$ & r, VA & ضعف رغبة مدير المدرسة في التطوير & 9 \\
\hline 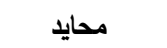 & . Aדr & $r, 1$. & المجموع & \\
\hline
\end{tabular}

يتضح من الجدول(· ( ) أن معوقات تفويض الصلاحيات لدى مديري المدارس لوكلائهم والتي تعود لمدير المدرسة جاءت

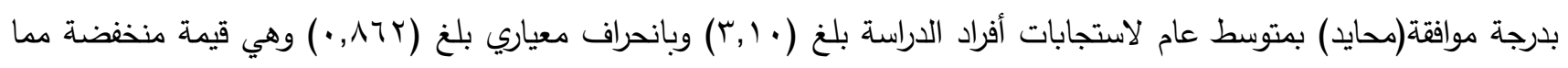
يعني تجانس أفراد العينة في تقديرهم لمعوقات تفويض الصلاحيات لدى مديري المدارس لوكلائهم والتي تعود لمدير المدرسة.

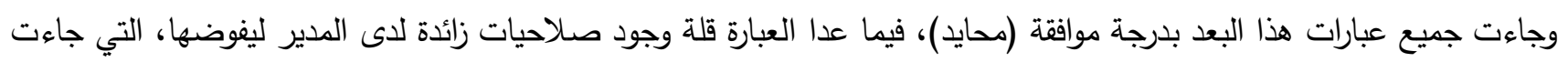

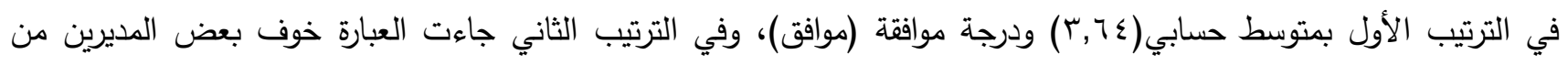

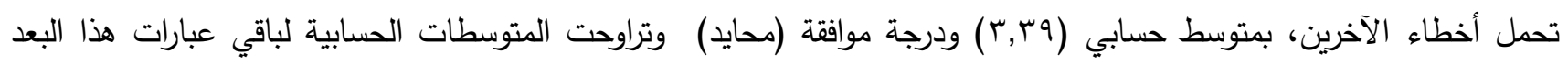

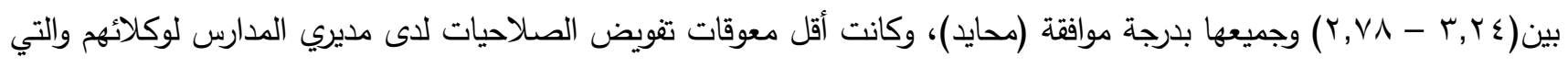
تعود لمدير المدرسة هي ضعف رغبة مدير المدرسة في التطوير ، حيث جاءت هذه العبارة في الترتيب الأخير بدرجة موافقة(محايد)

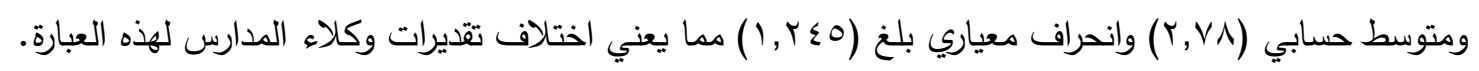


ويعتبر الباحثان المعوقات التي تحول دون ممارسة المدير لتويض صلاحياته للوكيل، تتمثل في رغبة المدير في تركيز السلطة في يده، وكذلك تمسكه بالروتين والخوف من فشل من يفوض إليهم الصلاحيات، وأيضًا الخوف من زيادة نفوذ الوكيل

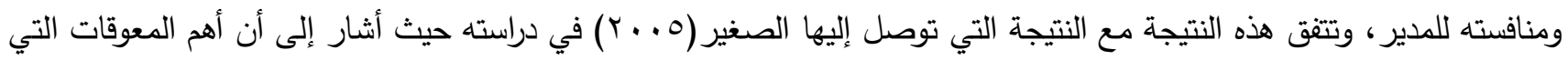

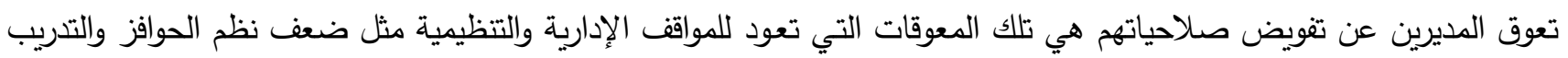

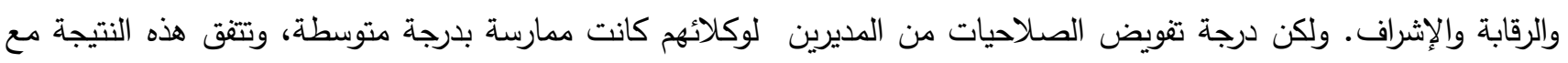

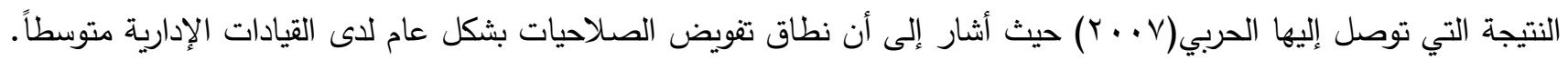

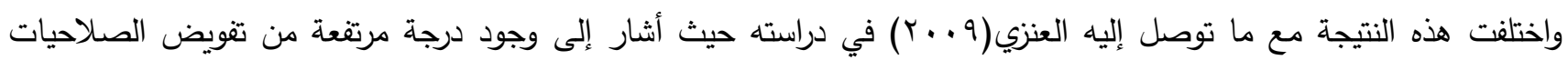
المنوحة لوكلاء المدارس • وربما يرجع هذا الاختلاف إلى طبيعة المجتمع التي أجريت فيه الدراسة. r. معوقات تفويض الصلاحيات لدى مديري المدارس لوكلائهم والتي تعود للوكلاء.

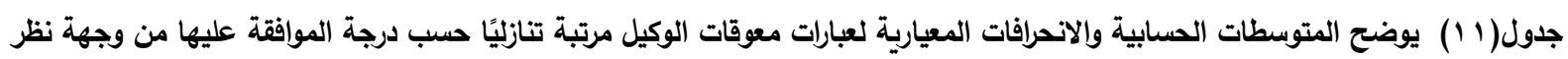

وكلاء مدارس التعليم العام الحكومية بمحافظة الطائف.

\begin{tabular}{|c|c|c|c|c|}
\hline درجة الموافقة & المعياري & الحستوسطي & 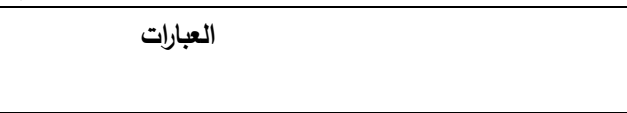 & م \\
\hline 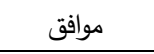 & $1,1 \cdot v$ & $r, \leqslant 7$ & عدم التزام بعض المرؤوسين بالقرارات والتعليمات الإدارية & 1 \\
\hline 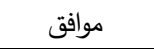 & $1, \cdot 11$ & $r, \varepsilon r$ & سوء استغلال بعض المرؤوسين للصلاحيات المفوضة إليهح & r \\
\hline محايد & $1,1 \leq 7$ & r, rی & خوف بعض المرؤوسين من التعرض للمساءلة & r \\
\hline محايد & 1,111 & $r, r v$ & قلة الكفاءات على تحمل مسؤولية الصـلاحيات المفوض إليهج & $\varepsilon$ \\
\hline محايد & $1,1 \mathrm{VV}$ & $r, r q$ & ضعف روح التعاون بين المرؤوسين للصلاحيات المفوض إليهم & $\circ$ \\
\hline محايد & $1,1 \leqslant 1$ & $r, r$ r & عدم تقبل بعض المرؤوسين لمبدأ التقويض & 7 \\
\hline محايد & 1,171 & r, r & الاعتماد الزائد على المير في إنجاز جميع الأعمال & $\mathrm{V}$ \\
\hline 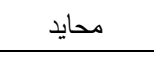 & $1,|v|$ & r, & ضعف ثقة بعض المرؤوسين في قدراتهم & $\wedge$ \\
\hline 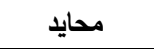 & $\cdot, \wedge 91$ & $r, r$ & 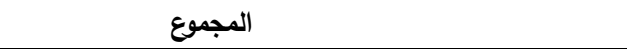 & \\
\hline
\end{tabular}

يتضح من الجدول(1) أن معوقات تفويض الصلاحيات لاى مديري المدارس لوكلائهم والتي تعود للوكلاء جاءت بدرجة

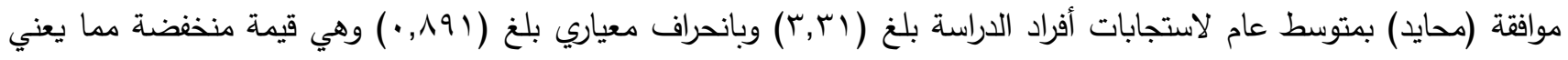

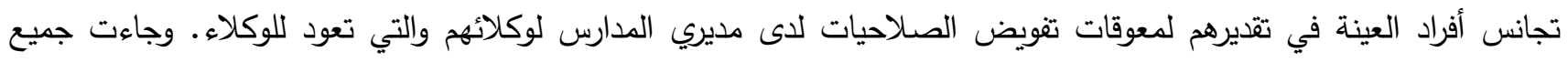

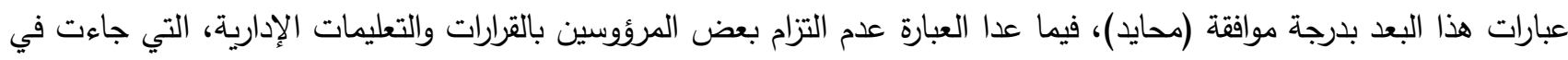

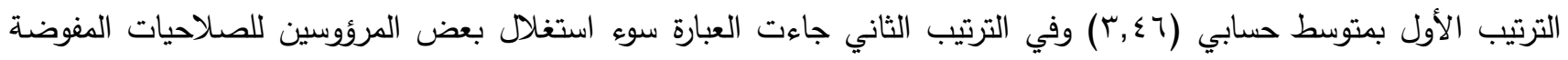

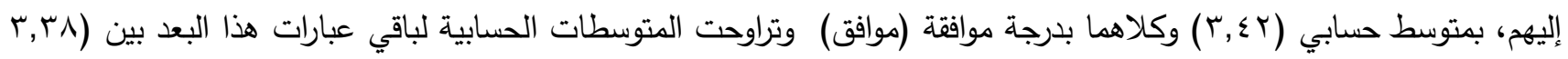

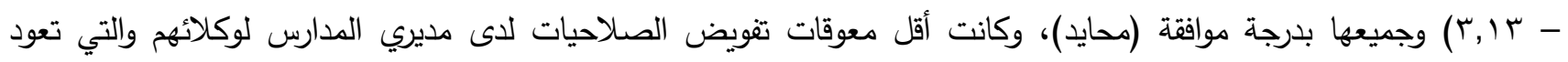
للوكلاء هي ضعف ثقة بعض المرؤوسين في قدراتهم حيث جاءت في الترتيب الأخير بدرجة موافقة(محايد) ومتوسط حسابي

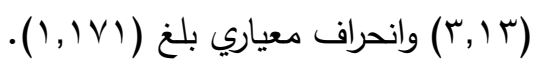
وهذا يعني اختلاف تقديرات وكلاء المدارس لهذه العبارة وربما يرجع هذا إلى ندرة الحوافز التشجيعية في العمل الإداري، وقلة

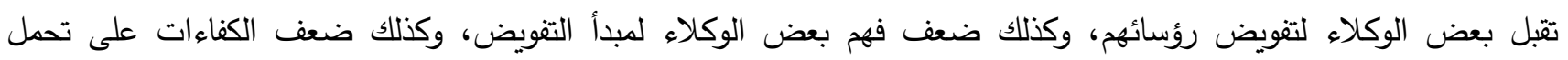

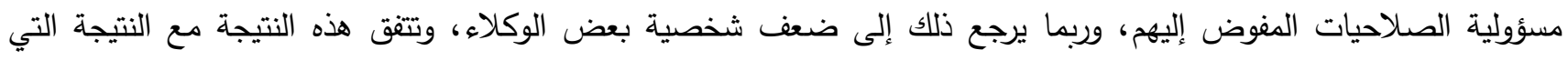

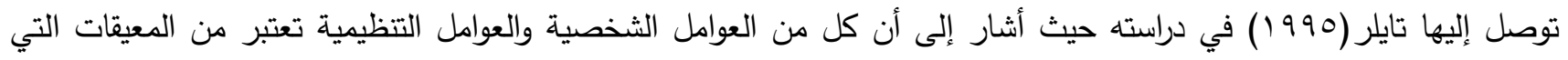
تؤثر في جهود المرؤوسين. 


\section{أهم النتائج التي توصلت إليها الدراسة:}

أولًا: ممارسة مديري المدارس لتفويض الصلاحيات لوكلائهم في التخطيط جاءت بدرجة ممارسة عالية بمتوسط عام لاستجابات أفراد عينة الدراسة بلغ(7, 97). وفي ذلك تأكيد على دور مدير المدرسة الفعال في وضع الخطط المدرسية وتحقيق أهدافها

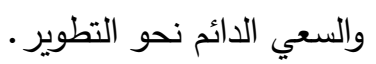

ثانيًا: ممارسة مديري المدارس لتفويض الصلاحيات لوكلائهم في التتظيم جاءت بدرجة ممارسة عالية بمتوسط عام لاستجابات

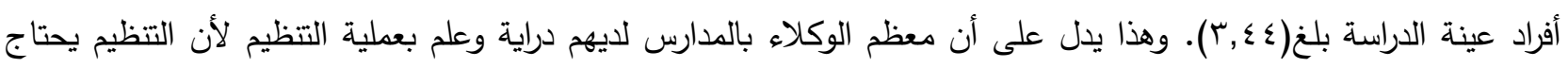
إلى مقدرة إدارية عالية من الوكلاء.

ثالثًا: ممارسة مديري المدارس لتفويض الصلاحيات لوكلائهم في الإشراف الفني جاءت بدرجة ممارسة عالية بمتوسط عام

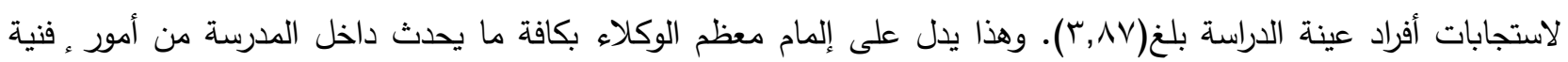
وإدارية. ويدل أيضًا على ثقة مديري المدارس بقدرة أحد الوكلاء بالإشراف الفني والإداري داخل الدان المدرسة. رابعًا: ممارسة مديري المدارس لتفويض الصلاحيات لوكلائهم في التقويم جاءت بدرجة ممارسة عالية بمتوسط عام لاستجابات

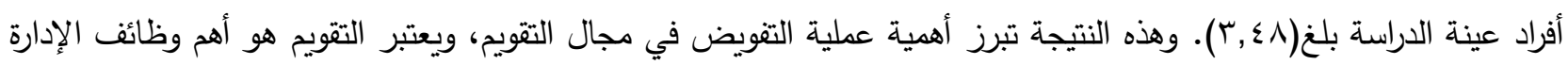
ويدل ذلك على أن مدير المدرسة يتقن وظيفة التقويم ويشرك فيها الوكلاء ولكن ليس بالقدر التئه الكافي.

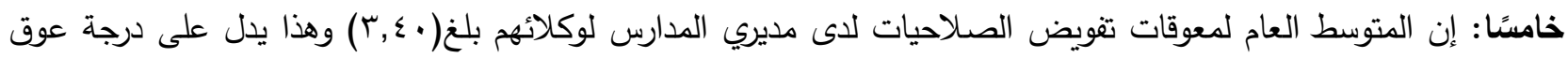

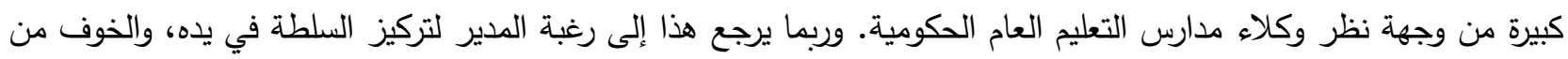

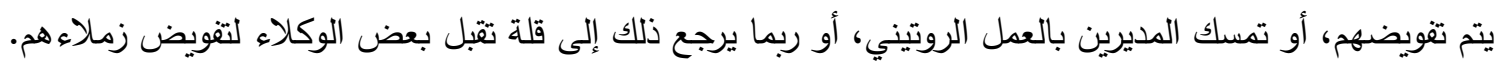

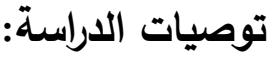

أولا: ضرورة التأكد على تطبيق تفويض الصلاحيات لوكلاء المدارس حيث تبين من نتائج الدراسة أن هنالك تباين في مستوى تطبيق أو تفعيل هذه الصلاحيات في عمليات التخطيط، والتنظيم، والإشراف الفني، والتقويم.

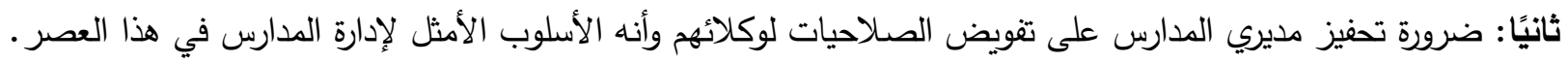

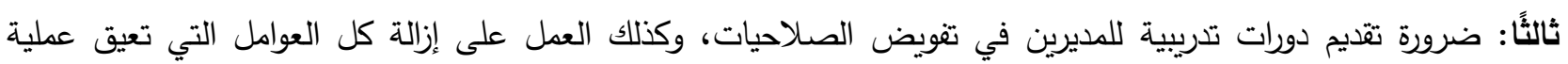

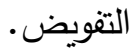
رابعًا: عمل ورش مناسبة عن تفويض الصلاحيات من خلال التركيز على التدريب والممارسة على تفعيل التقويض والتطبيق على مواقف علمية مفتعلة.

1. برس، يورك( (1 . ب): سلسلة الإدارة المثلى. لبنان: الناشر مكتبة لبنان ناشرون.

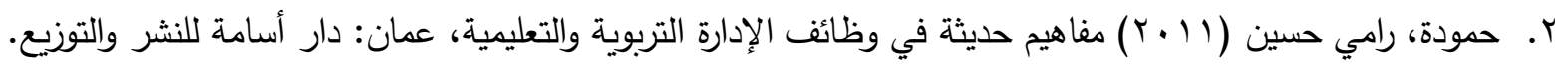

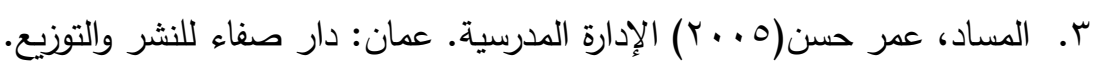
ع. وزارة المعارف(999(1)): القواعد التظظيمية لددارس التعليم العام. المملكة العربية السعودية.

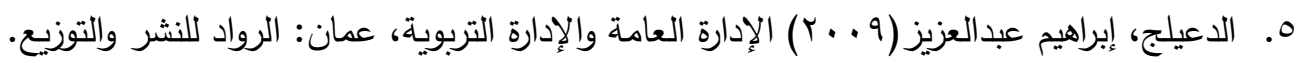

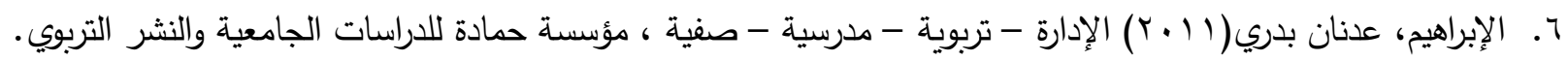

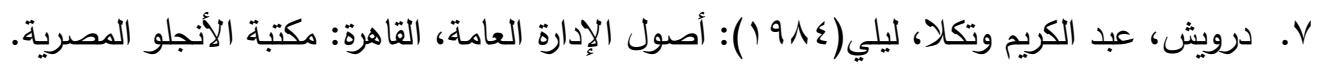

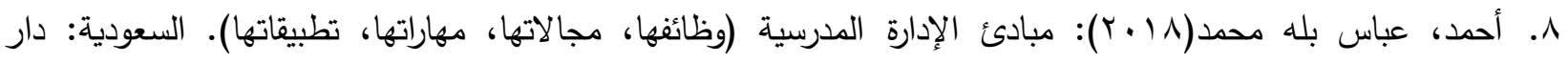
المتنبى. 


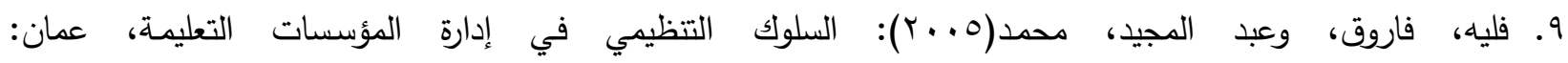
دار المسيرة.

• ( ـكنعان، نواف(9 . . ب): القيـادة الإداريـة، عمـان: دار الثقافة للنشر والتوزيـع، مطابع الأرز.

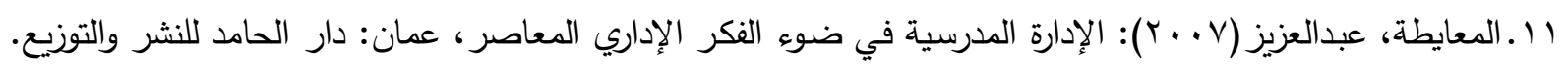

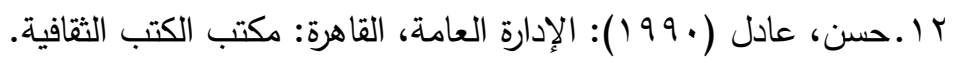

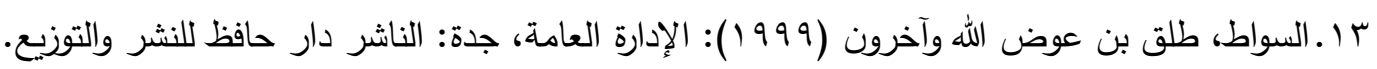

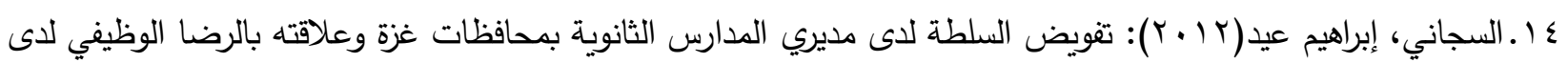

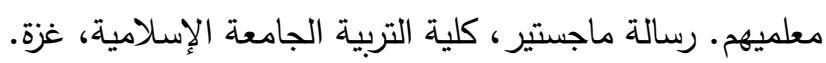

ه ـ العنزي، مبارك عبدالله(9 . . ب): علاقة تفويض الصلاحيات بالإبداع الإداري لدى وكلاء مدارس منطقة تبوك التعليمية من وجهة نظرهم. رسالة ماجستير ، كلية التربية، جامعة مؤتة.

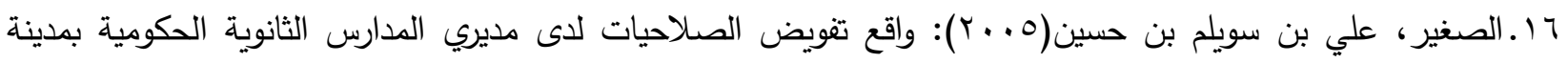

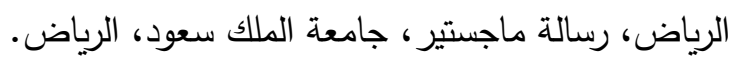

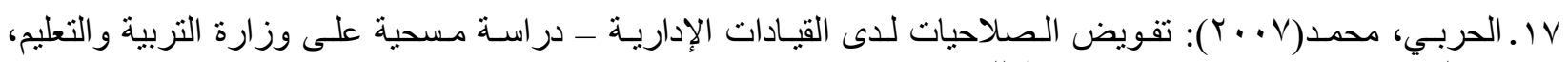
رسالة ماجستير غير منشورة، جامعة الملك سعود.

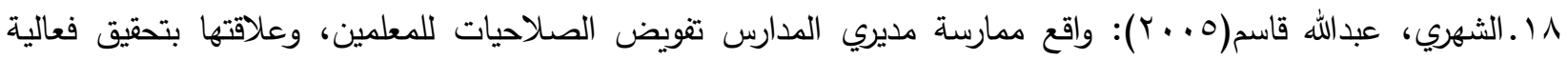
المدارس، رسالة دكتوراه، جامعة الملك خالد، أبها.

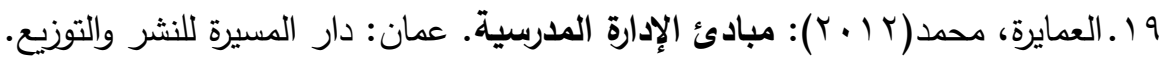

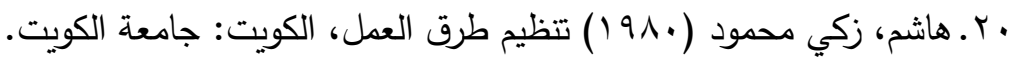

ثانياً: المراجع الأجنبية:

[1] TAYLOR, G RON (1995): the patterns of empowerment an examination of affecting employee- empowerment effects (participatory management) dissertation abstract $\mathrm{PhD}$, the university of Tennessee, database Yarmouk university.

[2] Carto, K Samuel (2007) Modern Management, Adding Digital Focus, Ninth Edition, Upper Saddle river, New Jersey, Person Prentice Hall. 


\title{
Investigating The Extent Of Schools Administrators Practice To The Process Of Authorizing Powers (Mandates) To Their Deputies From The Standpoint Of Deputies In Middle And Secondary Schools In The Province Of Al-Taif
}

\author{
Dr. Bannaga Taha El-Zubair \\ Assistant Professor- Dept. Of Foundations And Administration Of Education \\ Faculty Of Education, University Of Khartoum - Sudan. \\ banagataha@gmail.com
}

\section{Hassan Ebn Nawar Ebn Molhem El-Mugati}

Educational Supervisor - Education Office North Of Taif

Kingdom Of Saudi Arabia

\begin{abstract}
:
This study aims at investigating the extent of schools' administrators practice to the process of authorizing powers (mandates) to their deputies from the standpoint of deputies in middle and secondary schools in the province of Al-Taif. The researchers have used descriptive method, and the subject of the study included (354) deputies from which the researchers then randomly selected simple sample of about (120) deputy. Researchers have designed questionnaire for data collection and then analyzed through the program of statistical packages of social sciences (SPSS). The study has revealed a number of important findings such as: administrators of schools practice the process of mandating powers to their deputies in the highest average, challenges that heads of schools encountered in authorizing powers to their deputies was responded with the lower degree. In the light of these findings, the researchers recommended that there must be assurance for the application of power authorization to schools' deputies as well as motivating schools' administrators to mandate powers to their deputies. Also, there ought to be training sessions and workshops for the administrators around the issue of empowerment.
\end{abstract}

Keywords: Empowerment, Mandates. 